Dr. Khaled Nagib El-Sebaie Khalifa

\title{
Inheritance Rules in Surat Al-Nisa' (Women) as a Contemporary Reading of Two Translations; Y. Ali (1979) and M. Haleem (2004): An Appraisal Study
}

\author{
By \\ Khaled Nagib El-Sebaie Khalifa \\ Synopsis
}

The comparative study in translation represents a dichotomy that distinguishes the different perspectives of the translators to trace weaknesses and strengths, and to minimize failings and to maximize the benefits obtained, as a result of the translation. The two translations, Yusuf Ali's - the revised version in 1979 A. D. 1400 H., The Holy Qur'an: Text, Translation and Commentary, and Abdel Haleem's (2004) The Qur'an: a New Translation, reveal two different perspectives of translating the major issues in chapter four, Surat /?annisā?/ (i.e. women), as far as Cultural Translation and Authentic Translation are concerned.

As the issue studied is tentative, the two perspectives are discussed within the framework of J. Martin's 'Appraisal Model' (2007) and others, as it is interdisciplinary. The thesis is a comparative study between two translations about one of the most important issues of Surat /?annisā?/, that is highly debatable and controversial, which is The Inheritance Rules. The major differences between the two translations have been taken into consideration, with a view to differentiating between Cultural and Authentic translations. A considerable number of examples is presented and consolidated.

The paper uses the I. P. A. conventions for the Transcription of Arabic forms the Qur'anic verses.

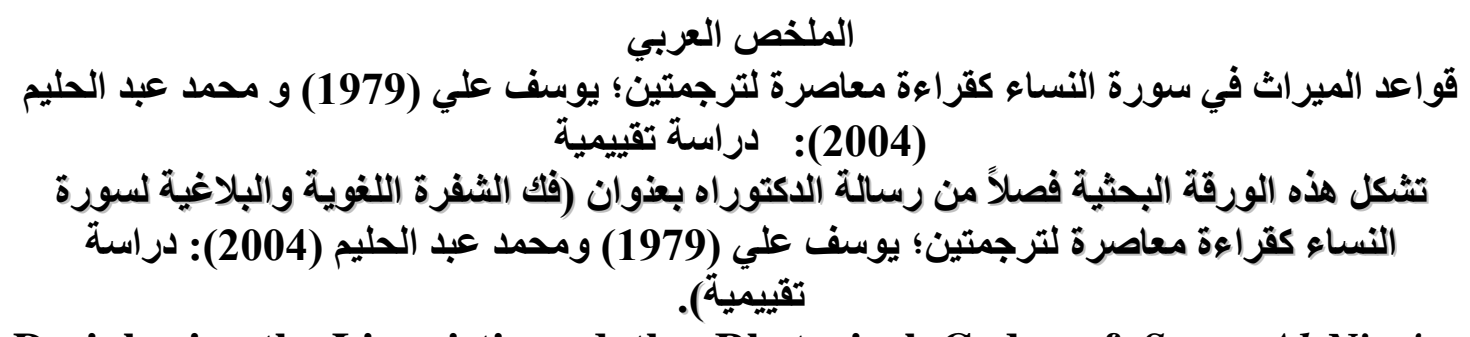

Deciphering the Linguistic and the Rhetorical Codes of Surat Al-Nisa' (Women) as a Contemporary Reading of Two Translations; Y. Ali (1979) and M. Haleem (2004): An Appraisal Study

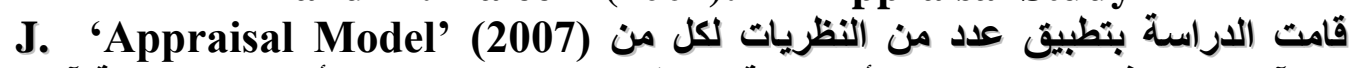
Martin الميراث على مدار السورة.

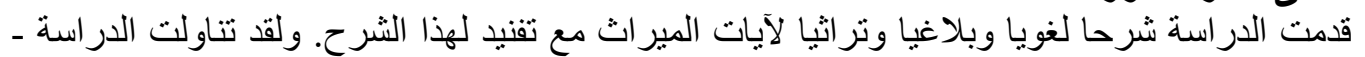

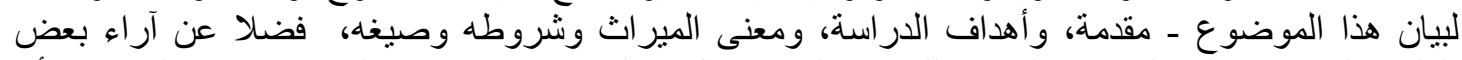

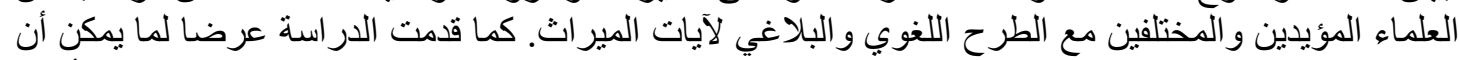

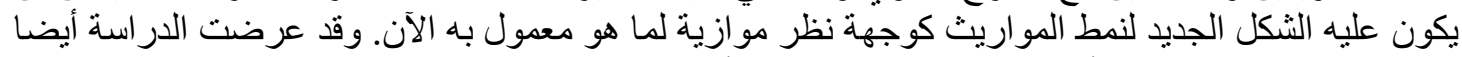

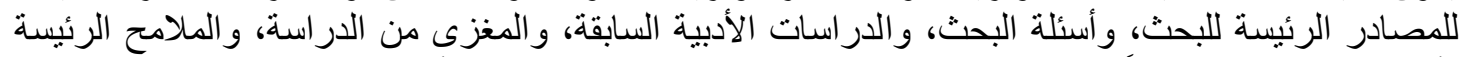

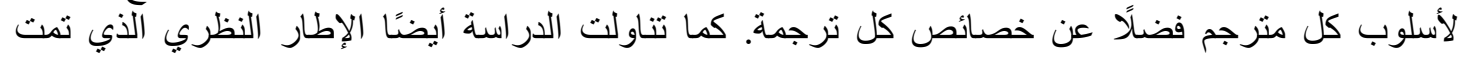

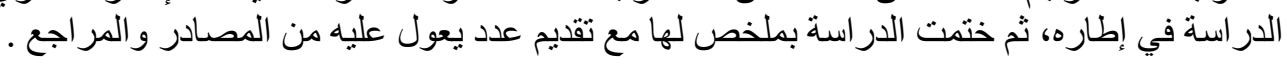




\section{Inheritance rules}

\subsection{Statement of the Problem}

Surat An-Nisa' has a number of ordinances belong to the inheritance rules, that many linguists or even jurisprudents, may be perplexed about them. So the researcher eagerly prefers to dispute some misunderstood concepts of these ordinances through setting an analytical comparison between the two translations.

The general trend of Qur'anic translations is that they are literally oriented. Such literality may cause loss, or damage of meaning, despite the fact that the majority of these translations are entitled with a word that denotes meaning. These mistranslations are considered clear evidence especially in the semantic fields of explanation of the issues at study, in which they relied much on the authentic meanings (i.e. 'dictionaries and thesauruses'). In this concern, the present study neither vilifies nor claims any previous or even current law/opinion.

According to Matthews (1997, p. 334), semantic field is a distinct part of the lexicon defined by some general terms which includes hyponyms. The two translations under investigation illustrate these five issues from a totally different stand point, to assert that hyponymy, in verses, surely leads to different comprehension.

According to Newmark (1984, p. 83), the most favored procedure for terms which are peculiar to a foreign culture is likely to be transcribed coupled with discreet explanation within the text. Consequently, the research presents a comparative study attempting to differentiate between the two translations through surveying the features of cultural and authentic translation, viewing which of them might be respectively accepted as follows:

Of Inheritance Rules, the study investigates the linguistic aspects of the overwhelming mathematical epistemological concepts: a) confinement to the four calculating operations - adding, sub-traction, multiplying, and dividing - rather than the totally ignored operation percentage, as a calculating operation, through surveying the function of a number of quantifiers, which the Text has relied much on. b) the policy of mingling the inheritance rules between men and women in the periods of Omayyads $50^{\text {th }} \mathrm{H}$., and Abbasids $132^{\text {nd }} \mathrm{H}$., (i.e. the people where the inheritance rules have been initialized, crystallized and settled in their period). These epistemological concepts play an important role in disputing such problem. The study attempts to deal with the problematic issues of many interpretations or exegeses, applying the linguistic facts rather than the mathematical ones. 


\section{Dr. Khaled Nagib El-Sebaie Khalifa}

The researcher, however, does not deny the previous efforts the jurisprudents already exerted viewing and reaching consistent applicable rules of Inheritance. The researcher asserts that issues of Bequest and Inheritance which are mentioned in the Text, their applications among the late fourteen centuries according to the jurisprudents' comprehension, and the religious cultural notion of each territory in the Islamic world about Bequest and Inheritance, all of them affect deeply the collective Islamic mind as well.

Martin's (2007) Attitudinal Positioning, under the sub-type Intertextual positioning, discusses the same notion, asserting that we are concerned with uses of language by which writers/speakers adopt evaluative positions towards what they represent as the views and statements of other speakers and writers, as deriving from outside sources. At its most basic, intertextual positioning is brought into text when a writer/speaker chooses to quote or reference the words or thoughts of another. Strictly speaking, intertextual positioning is also a sub-type of dialogistic positioning. Such attributions can be seen as dialogistic from several perspectives. This is discussed in detail in the analysis and discussion.

\subsection{Aim of the Study}

The paper aims at investigating the two translations under study to clarify which technique each of them uses, and examining to what extent each of them is more competent and accurate in rendering the inheritance verses directly from the Sura under study. Specifically, it aims at deducing the forms and the functions of semantic and rhetorical devices, indentifying the syntactic structure in both STs and TTs, and to show the difference between the individual's translation, by Abdel Haleem, and Yusuf Ali's translation, which is revised by a number of scholars, through applying Martin's (2007) Appraisal Model and others. Moreover, the study attempts to present a suggested translation of a number the problematic issues that, textually and semantically, correspond to the requirements of the evaluative criteria.

\subsection{Research Questions}

For the intricate nature of the topic, the research questions vary. So, they relate to TTs, and STs.

1- What are the forms and functions of the semantic and rhetorical devices of the verses under study of Surat Al-Nisa'?

2- What is the syntactic structure of the verses?

3- Which of the two translations, of Abdel Haleem (as an individual), or of Yusuf Ali (as a group of scholars), succeeds in 
rendering the inheritance verses, considering the appraisal model into English?

4- Which of the two translations gets rid of the traditional cultural heritage about the idea of inheritance, and acts neutrally while rendering the translation?

\subsection{Methodology of the Study}

The researcher attempts to set a comparison between the two translations in detail. The study, here, investigates the inheritance verses that present the entire framework of the main issues to be discussed. According to the evaluative criteria of translation, the study, however, attempts to trace this issue through applying Martin's appraisal model and others, viewing the differences and the correspondences that may come out of this comparison. Finally, the study presents views of critics who consolidate the suggested translation.

\subsection{Scope of the Study}

Lately, through media programs such as the TV talk show programs that host Jurists and Mofties, the scientists who are in charge of Ifta, (i.e. 'individuals who undertake the ordinances'), and Radio programs as well, many voices have risen asking for reviewing the interpretation of the inheritance verses. On the other hand, for example, the Islamic world, mostly, does not give women their inheritance properties, specially, in the very close-cultured communities, taking into consideration that women come in the second category in humanity, or they do not deserve their portions, as they are already entitled to be maintained within the first category, (husband or brother). Hence, courts are full of inheritance cases against men for that reason.

Rereading the verses at study, in the two translations, the researcher has found a number of diversions occurring by the two translators, concerning what it is (i.e. 'The Text'), and what it would be (i.e. 'the translation'). A sort of resemblance has been realized by the two translators while doing the translations, considering the Qur'anic Text/ST as a literary text/TT. Ignoring a great number of rhetorical images is resulting into a sort of decollage.

This paper presents an investigation of integrated variant theories, thoroughly applied to the inheritance verses, to uncover the most appropriate method to translate it, through a linguistic disputing of the dogmatic problems, reaching to an ideal form of translation, out of bias, partiality or fanaticism. Such study, to my knowledge, has not been attempted before. Using the Appraisal Technique, the study will be able to evaluate the TTs of Surat Al-Nisa' in an authentic manner. 


\section{Dr. Khaled Nagib El-Sebaie Khalifa}

\subsection{Rationale of the Study}

The rationale of the present paper is two-fold. Cultural translation and authentic translation mostly, are common artefacts of the Qur'anic translation running according to a previous, settled and formatted idea reflects to what extent such idea is a deep-rooted one in the Islamic collective mind. At the cultural level, translation as a translator-based operation (monoglossic) is easy reading, more natural, simpler, clearer, more direct, superficial, conventional, and conforming to particular register of language, but a little bit longer. As such, translation is considered a satisfying compensation to the readers as it is overwhelming the reader's mentality. At the authentic level, translation as a Textlanguage-based (heteroglossic) is usually more awkward, more detailed, difficulty credible, more complex, deeper, but briefer, Newmark (1984, p. 42, 1988, p. 48).

That is, a multi-functional (scopos) translations do not substitute each other or even preferred to another; rather, every translation is considered a means of the meaning transition. Different levels of translation; culturally and authentically, have their affordances and constraints, hence are worthy of study.

\subsection{Sources of Data}

1- Yusuf Ali (1979). The Holy Qur'an: Text, Translation, and Commentary.

2- Abdel Haleem (2004). The Qur'an: a New Translation.

\subsection{Translations at Study}

\subsubsection{Ali's Translation}

A number of individuals have, in the past, ventured to translate the Qur'an, but their works have generally been private attempts, greatly influenced by their own prejudices. The version at hand is not his first original one (1938), but it is the revised version by a group of scholars (1979), dated 1400 A. H. by the Custodian of the Two Holy Mosques, King Fahd Ibn Abdul Aziz, in order to produce a reliable translation free from personal bias, and to undertake the responsibility of revising and correcting a particular translation which would be selected for this purpose to be publicly available later.

To accomplish this enormous task, a committee was formed, comprising well-qualified scholars; both in Islamic Shari'a, and the English language. Some of these scholars were associated with the General Presidency of the Departments of Islamic Researches, Ifta, Call and Guidance. The committee was given the task of examining the existing translations and choosing the most suitable one from among them. The committee discovered that there was no translation free from defects, so, there were two options open for consideration. The first was 
to select the best translation available and then adopt it as a base for further work as well as a source of reference, with the objective of revising its contents and correcting any faults, in view of the objections raised against it. The second was to prepare a fresh and independent translation, starting from scratch. It became obvious from studying these translations that the second option demanded much time and effort, neither of which was available at the time.

The first option was, therefore, considered to be more practical, since it met the existing urgent requirements and helped to achieve the desired goal in a comparatively short period of time. The translation by Abdullah Yusuf Ali was consequently chosen for its distinguishing characteristics, such as a highly elegant style, and convenient choice of words that are close to the meaning of the original text, accompanied by scholarly notes and commentaries.

The committee began revising and correcting this translation with the aid of other available translations, by comparing and then adopting the best expressions, as well as by introducing fresh expressions where necessary. The committee was fully aware of all the criticisms that had been directed against this translation and which had been carefully brought to the notice of the presidency by a number of academic bodies and other involved parties. The committee, however, was set up to collate all the suggestions. It compared all of the suggestions regarding specific issues, selected the appropriate one(s), thus, arrived at a text as authentic and defect-free as possible. Finally, the committee had to finalize the text by adopting the most accurate expression where needed, besides checking the notes vigilantly so as to clarify thoughts not in conformity with the sound Islamic point of view.

In the course of its work, the committee came across some Arabic words which could not be translated correctly, such as /?azzakāt/ and /?attā $\gamma \bar{u} t /$. It was therefore decided to give a transliteration of these words in English with a brief explanatory note for each one at its first occurrence in the text. According to the Royal decree (No. 12412, dated, 27/10/1405 H.), this translation is printed at King Fahd Holy Qur'an printing Complex in Al-Madinah Al-Munawarah, and with coordination of the guidal presidency of the Departments of Islamic Researches, Ifta Call and Guidance as well. (Paraphrased from the preface of the version at study, p. 5-7).

\subsubsection{Haleem's Translation}

In his version, Abdel-Haleem presents a very long introduction amounting to 60 pages. He adds that the Qur'an is the supreme authority 


\section{Dr. Khaled Nagib El-Sebaie Khalifa}

in Islam. It is the fundamental and paramount source of the creed, rituals, ethics, and laws of the Islamic religion. It is The Book that 'differs' between what is right and what is right wrong, so that nowadays, when the Muslim world is dealing with such universal issues as globalization, environment, combating terrorism and drugs, issues of medical ethics, and feminism, evidence to support the various arguments are sought in the Qur'an.

This supreme status stems from the belief that the Qur'an is the word of God, revealed to the Prophet Muhammad (PBUH) via the arch angel Gabriel, and intended for all times and places. His introduction includes the notion of The Revelation of the Qur'an, saying: "Muhammad's own account survives of the extraordinary circumstances of the revelation, of being approached by an angel who commanded him: "Read in the name of your Lord". When he explained that he could not read, the angel squeezed him strongly, repeating the request twice, and then recited to him the first two lines of the Qur'an.

Haleem gives a bird's eye view describing some Stylistic Features, where he says: "The Qur'an has its own style". It may be useful to readers to mention some of the important features of this style. The reader should not expect the Qur'an to be arranged chronologically or by subject matter. The Qur'an may present, in the same Surah, material about the unity and grace of God, regulations and laws, stories of earlier prophets and nations and the lessons that can be drawn from these, and descriptions of rewards and punishments on the Day of Judgment. This stylistic feature aids to reinforce the message, to persuade and to dissuade.

This technique may apparently seem to bring repetition of the same themes or stories in different Suras but, as the Qur'an is above all a book of guidance, each Sura adds to the fuller divorce and settlements. The Sura suspends the introduction of regulations and instructs the believers to keep up prayer and stand in obedience to God (Surat Al-Baqarah, pp. 237-8), later to resume discussion of the divorce regulations."

Haleem also presents, within his introduction a number of topics such as, The General style of the present Translation, Intersexuality, Context, Identifying Aspects of Meaning, Arabic Structure and Idiom, Pronouns, and Classical Usage, where he widely clarifies each. (Paraphrased from the introduction of the version at study, pp. 5-65).

\section{Language and Rhetoric: Ali vs Haleem (Application). \\ 2.0. Introduction}

This paper is an attempt to solve the problems we encounter that result from the applications of the verses of bequest and inheritance. The 
researcher attempts to determine such problems, trying to comprehend and apply them according to specific settled linguistic and rhetorical facts. The researcher, in this, exceeds the ancient mathematical, social, and political epistemologies, concentrating only on the linguistic facts, and taking into account the repetition of the words bequest as money to give, which oscillates in two parts of speech; noun and verb (twelve times), and inheritance, as money to get, taking the form of verb (three times).

\subsection{Bequest and Inheritance}

Bequest is mentioned in (2/180), (2/240), (4/11 four times), (4/12 five times), and (5/106), and inheritance is mentioned in (27/16), (4/11), and (4/12). Revising the practiced and in use jurisprudence, the researcher finds that:

1- The current law, which takes its main format directly from the Islamic jurisprudence, insists on giving the highest priority to the inheritance not to the bequest.

2- It mingles in a way that seems unjustified between /?alhað̦రָ/ and /?a-nnaşīb/ (i.e. 'fortune and portion'), and considers both of them the same, where it, the current law, neglects the Lord's saying: /li-rrigāli naşībun mimmā taraka-lwālidāni wa- l?aqrabūna .../

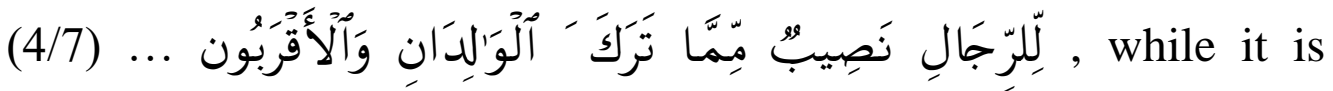
considered the main preliminary determiner frame work of the inheritance.

3- The current law considers the Lord's saying: /fa? in kunna nisā?an fawqa- $\theta$ natayni/

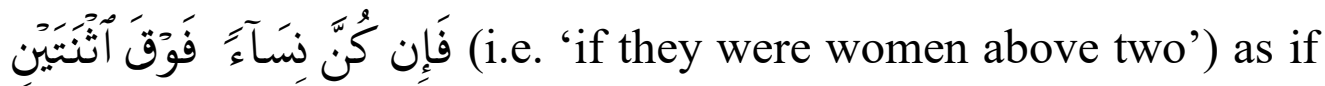
it is 'if they were two females and more', where there is a considerable difference between both.

4- It considers, in the inheritance verses, the boy (i.e. 'the brother') prevents يحجُ the girl (i.e. 'his sister'), and she does not prevent him, where the researcher sees that this is considered an obvious penetrating of the verse /yūşīkumu-llāhu fì ?awlādikum li-

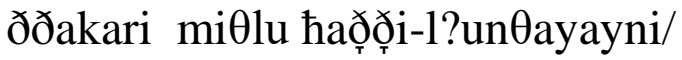

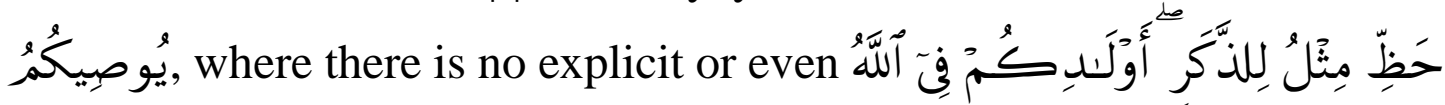

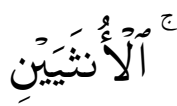




\section{Dr. Khaled Nagib El-Sebaie Khalifa}

implicit hint refers to such matter.

5- The current law gives some portions, of the inheritance, to individuals are not mentioned or even hinted at the Text (i.e. 'the paternal uncles'), and this creates confusion and misunderstanding, and creates a sort of malevolence between the members of the bigger family as well.

6- The current law dispossesses the orphan grandsons from the inheritance of their grandfather, in case of the death of their father before the grandfather, though they are already mentioned in the Text, and it favored them the so-called /?alwaşyyah ?alwājibah/ الوصية الو اجبة.

7- The researcher would like to bring to the reader's attention that bequest is related to people who have a biological relationship and to the close relatives who are not apparent heirs, and the inheritance is related to people who are responsible for guardianship and patronage, whether they have a biological relationship or not.

Verse (4/11) asserts that meaning, where it begins in a biological relationship, and ends in guardianship relation.

وتتتهي ب (آباؤكم بيولوجية مجردة، حيث تبدأ الآية ب (بوصيكم الله في أولادكم) و هي علاقة

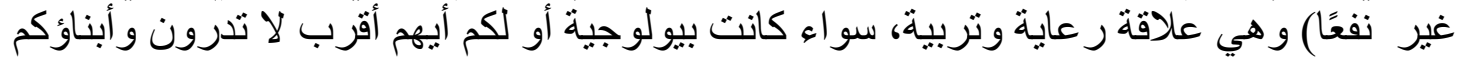
ذلك.

Assuyuty, G. A. (1445-1505 A. D.) (849-911 H.), says:

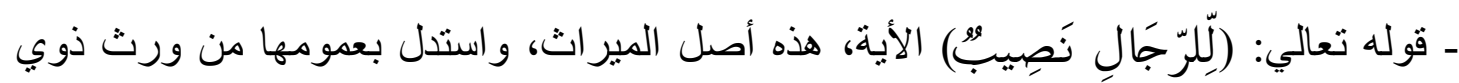

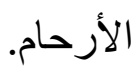

God says: (For men is a portion) is the fundamental of inheritance, and he uses it as an evidence for inheritance of cognation. (The researcher translation).

Table 1: Componential Analysis of Bequest and الوصية والميراث Inheritance

\begin{tabular}{|c|c|c|c|c|c|c|c|c|c|c|c|}
\hline parameters & $\begin{array}{c}\text { concrete/real } \\
\text { (money to } \\
\text { give) }\end{array}$ & $\begin{array}{c}\text { biological } \\
\text { relation }\end{array}$ & $\begin{array}{c}\text { non-biological } \\
\text { relation } \\
\text { (father, } \\
\text { mother, son, } \\
\text { daughter and } \\
\text { brother) }\end{array}$ & $\begin{array}{c}\text { up-down } \\
\text { action } \\
\text { (begetters } \\
\text {-to- } \\
\text { offspring) }\end{array}$ & $\begin{array}{c}\text { down-up } \\
\text { action } \\
\text { (offspring } \\
\text {-to- } \\
\text { begetters) }\end{array}$ & $\begin{array}{c}\text { family } \\
\text { blood } \\
\text { line }\end{array}$ & $\begin{array}{c}\text { during } \\
\text { one's } \\
\text { life }\end{array}$ & $\begin{array}{c}\text { after } \\
\text { one's } \\
\text { death }\end{array}$ & willingly & obligatory & bound \\
bequest & + & + & & + & + & + & + & & + & + & + \\
\hline inheritance & + & + & + & + & + & + & & + & & + & + \\
\hline
\end{tabular}


Inheritance Rules in Surat Al-Nisa' (Women) as a Contemporary Reading of Two Translations; Y. Ali (1979) and M. Haleem (2004): An Appraisal Study

Table 2: Componential Analysis of Bequest and الوصية

\begin{tabular}{|c|c|c|c|c|c|c|c|c|c|}
\hline parameters & $\begin{array}{c}\text { concrete/real } \\
\text { (money to } \\
\text { give) }\end{array}$ & $\begin{array}{c}\text { abstract/moral } \\
\text { (action to } \\
\text { do) }\end{array}$ & $\begin{array}{c}\text { God-man- } \\
\text { man } \\
\text { relation }\end{array}$ & $\begin{array}{c}\text { God- } \\
\text { man } \\
\text { relation }\end{array}$ & $\begin{array}{c}\text { man- } \\
\text { man } \\
\text { relation }\end{array}$ & $\begin{array}{c}\text { biological } \\
\text { relation }\end{array}$ & $\begin{array}{c}\text { non- } \\
\text { biological } \\
\text { relation }\end{array}$ & $\begin{array}{c}\text { boun } \\
\mathrm{d}\end{array}$ & $\begin{array}{c}\text { fre } \\
\mathrm{e}\end{array}$ \\
\hline bequest & + & & + & + & + & + & & + & \\
\hline $\begin{array}{c}\text { recommendati } \\
\text { on }\end{array}$ & & + & & + & + & & + & & + \\
\hline
\end{tabular}

\subsection{Portion and Fortune}

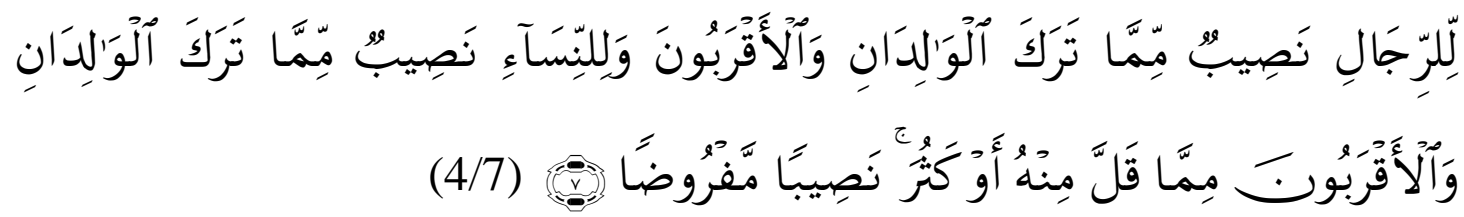

/li-rrigāli naşībun mimmā taraka-lwālidāni wa-l?aqrabūna wali-nnisā?i naşībun mimmā taraka-lwālidān iwa-l?aqrabūna mimmā qalla minhu ?aw kaӨura naşībam - mafrūđan/

Ali translates: From what is left by parents and those nearest related there is a share for men and a share for women whether the property small or large, a determinate share.

Haleem translates: Men shall have a share in what their parents and closest relatives leave, and women shall have a share in what their parents and closest relatives leave, whether the legacy be small or large: this is ordained by God.

The researcher translates: For men is a portion from what the begetters and closest relatives left, and for women is a portion from what the begetters and closest relatives left, whether it was small or large: an ordained portion.

The recursion of the noun clause, /naşībun mimmā taraka-lwālidāni wa-l?aqrabūna/, (i.e. 'a portion from what the begetters and closest relatives left'), reflects that attribution of the apparent heirs is concerned and intended. The following componential analysis may illustrate the point. 


\section{Dr. Khaled Nagib El-Sebaie Khalifa}

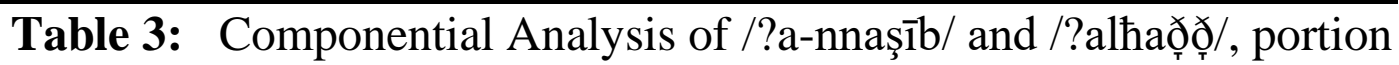
النصيب و الحظ and fortune

\begin{tabular}{|c|c|c|c|c|c|c|c|c|c|c|c|c|c|c|c|}
\hline $\begin{array}{c}\text { parame } \\
\text { ters }\end{array}$ & $\begin{array}{l}\text { defi } \\
\text { nite }\end{array}$ & $\begin{array}{l}\text { indefi } \\
\text { nite }\end{array}$ & $\begin{array}{l}\text { inherita } \\
\text { nce }\end{array}$ & $\begin{array}{l}\text { bequ } \\
\text { est }\end{array}$ & $\begin{array}{c}\text { biologi } \\
\text { cal }\end{array}$ & $\begin{array}{l}\text { attribut } \\
\text { ion } \\
\text { (men/ } \\
\text { women }\end{array}$ & $\begin{array}{c}\text { gend } \\
\text { er } \\
\text { (mal } \\
\text { e/ } \\
\text { fem } \\
\text { ale) }\end{array}$ & $\begin{array}{l}\text { the } \\
\text { famil } \\
y \\
\text { blood } \\
\text { line }\end{array}$ & $\begin{array}{l}\text { the } \\
\text { most } \\
\text { relativ } \\
\text { es }\end{array}$ & $\begin{array}{l}\text { parents } \\
\text { (father/ } \\
\text { mother } \\
\text { )sons, } \\
\text { and } \\
\text { daught } \\
\text { ers } \\
\end{array}$ & $\begin{array}{c}\text { begette } \\
\text { rs/ } \\
\text { offspri } \\
\text { ng }\end{array}$ & $\begin{array}{c}\text { Stan } \\
\text { ce } \\
\text { of } \\
\text { life }\end{array}$ & $\begin{array}{c}\text { Stan } \\
\text { ce } \\
\text { of } \\
\text { life } \\
\text { and } \\
\text { deat } \\
\mathrm{h} \\
\end{array}$ & $\begin{array}{c}\text { bou } \\
\text { nd }\end{array}$ & free \\
\hline $\begin{array}{c}\text { /?a- } \\
\text { nnaşib// }\end{array}$ & + & & + & & + & + & & + & + & + & & & + & + & \\
\hline |?:alhặ̆ọ & & + & & + & + & & & + & & & + & + & & & \\
\hline
\end{tabular}

Money wisely, being the word /haợ̆/ (i.e. 'fortune') reflects the stance of life, is perfectly asserted through verses number (4/11), (4/176), (28/79), (41/35), (3/176), (5/13), and (5/14) (7 times). Being the word /nnaşīb/ (i.e. 'portion') reflects the stance of life and death is asserted through verses number (2/202), (4/7) (thrice), (4/32) (twice), (4/53), (4/85), (4/141), (42/20), (3/23), (4/44), (4/51), (4/118), (6/136), (16/56), (40/47) (28/77), (7/37), (4/33) and (11/109) (21 times). (Al-Dalil Al-Mufahras, pp. 381, 875).

\subsection{Syntagm and Paradigm S S S البنية الأفقية والبنية الرأسية}

Syntagmatic relation and paradigmatic relation are introduced by Saussure (1974) to distinguish two kinds of signifiers: one concerns positioning (syntagmatic) and the other concerns substitution (paradigmatic). Paradigmatic relations are related to morphology and other knowledge organization systems, while syntagmatic relations are related to co-occurrences in the context. Asher (1994) asserts that syntagmatic relation is a type of semantic relations between words that co-occur in the same sentence or text. Paradigmatic relation is a different type of semantic relations between words that can be substituted with another word in the same categories (Hjorland, 2014). Khoo and $\mathrm{Na}$ (2006) points out that semantic relations could also refer to relations between concepts. Sahlgren (2006) argues that paradigmatic relation relates entities that do not co-occur in the text. However, Evens, Litowitz, Markowitz, Smith, and Werner (1986) clarify that paradigmatic relations could be expressed syntagmatically.

In this concern, the researcher focuses on how syntagmatic relation and paradigmatic relation can exist at the same time empirically, and may be employed, integratedly, with each other clarifying the following sentences: 

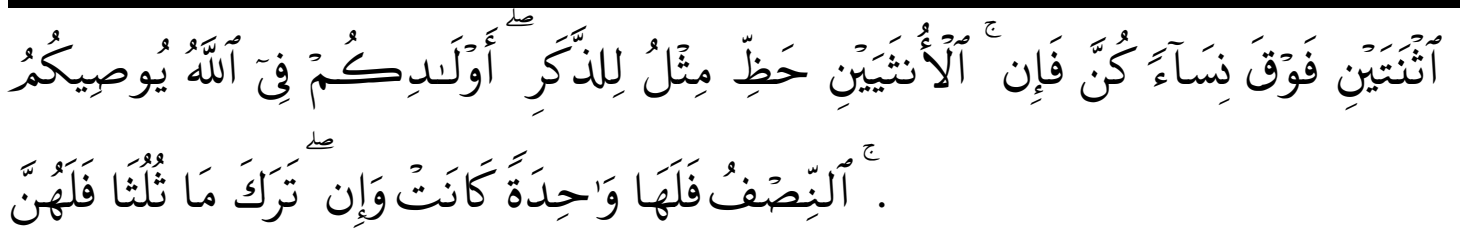

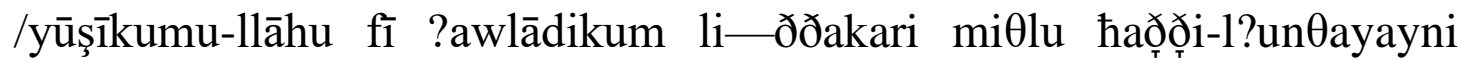
fa?in kunna nisā?an fawqa-Onatayni falahunna $\theta u l u \theta \bar{a}$ mā taraka wa?in kānat wāhidatan falaha-nnişfu/

Ali translates: Allah, thus, directs you as regards your children's (inheritance): to the male, a portion equal to that of two females: if only daughters two or more, their share is two-thirds of the inheritance; if only one her share is a half.

Haleem translates: Concerning your children, God commands you that a son should have the equivalent share of two daughters. If they are only daughters, two or more should share two-thirds of the inheritance, if one, she should have half.

Ali and Haleem translate the word /yūşīkum/ into directs and concerning using, culturally, the technique of substitution instead of the technique of equivalence. As well, they translate the word /?awlādikum/ into children using the technique of graduation 'monoglossia' instead of the technique of 'heteroglossia'. In this sense, there is a considerable variation between children and offspring concerning the biological relation among them. 'Offspring' reflects pure biological relation (diachronic relation) and 'children' reflects caring and growing relation when one's children are still young (synchronic relation).

Rhetorically, and using the same technique of substitution, Ali translates the word /nisā?an/ into females. In this, he uses the subcategorization of noun, as he transfers meronymy, a term used to denote a thing that is a part of something else. (Miller, p. 38), into hyponymy, a word or phrase whose semantic field is included within that of another. (Manfred, pp.93-99). Not only did Ali, but Haleem also transfers 'gender' into 'attribution' when he translates /nisā?an/ into 'daughters'.

In an another rhetorical addition, logical fallacy, a misconception resulting from faulty reasoning, the researcher would like to argue that a sort of indeliberate misconception has chronologically occurred to this sentence.

Using, by Ali and Haleem, the quantifiers, 'two or more' as a TT does not fit the ST, where 'two' is excluded and 'more' is included. Of the researcher, 'more' reflects 'number' where it could be translated into أكثر, while 'over' reflects 'percentage' where it could be translated into فوق , in which they seem more appropriate. 


\section{Dr. Khaled Nagib El-Sebaie Khalifa}

The researcher translates: Concerning your offspring, God recommends to you: for the male is like the fortune of the two females; if they were women over two, they will have two-thirds of what he left; if she was one, she will have the half.

Table 4: Syntagm and paradigm of the sentence 'for the male is like the fortune of the two females'

\begin{tabular}{|c|c|c|c|c|c|c|c|c|c|c|c|}
\hline \multicolumn{11}{|c|}{$\rightarrow$ Syntagmatic $\leftarrow$} & \multirow{2}{*}{$\begin{array}{l}\text { Relationship } \\
\mathrm{s}\end{array}$} \\
\hline \multicolumn{3}{|c|}{ Axis $C \downarrow$} & \multicolumn{4}{|l|}{ Axis B $\downarrow$} & \multicolumn{4}{|c|}{ Axis A $\downarrow$} & \\
\hline 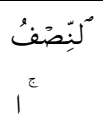 & فَلَهَا & كَانَتُ وَإِنَ & تَرَكَكَ مَاَ ثَلْنَّا & فَلَكُنَ & فَوَقَق فَسَاَكًَ & فَكَإن & 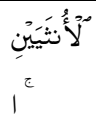 & حَظ & مِنقُلُ & لِلِنَّكر & \multirow{6}{*}{$\begin{array}{l}\uparrow \\
\text { Paradigmati } \\
\mathrm{c} \\
\downarrow\end{array}$} \\
\hline $\begin{array}{l}\text { the } \\
\text { half }\end{array}$ & $\begin{array}{l}\text { she } \\
\text { will } \\
\text { have }\end{array}$ & $\begin{array}{l}\text { if she } \\
\text { was one }\end{array}$ & $\begin{array}{l}\text { two- } \\
\text { thirds of } \\
\text { what } \\
\text { he left }\end{array}$ & $\begin{array}{l}\text { they } \\
\text { will } \\
\text { have }\end{array}$ & $\begin{array}{l}\text { women } \\
\text { over two }\end{array}$ & $\begin{array}{l}\text { if } \\
\text { they } \\
\text { were }\end{array}$ & $\begin{array}{l}\text { of the } \\
\text { two } \\
\text { female } \\
\text { s }\end{array}$ & $\begin{array}{l}\text { luc } \\
\mathrm{k}\end{array}$ & like & $\begin{array}{l}\text { for the } \\
\text { male } \\
\text { is }\end{array}$ & \\
\hline 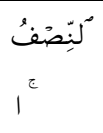 & فَلَهَا & كَانَتُ وَإِنَ & 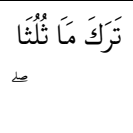 & فَلَكُنَّ & فَوَقَقَ نَسَاَكًَ & فَكَإن & - & - & - & - & \\
\hline $\begin{array}{l}\text { the } \\
\text { half }\end{array}$ & $\begin{array}{l}\text { she } \\
\text { will } \\
\text { have }\end{array}$ & $\begin{array}{l}\text { if she } \\
\text { was one }\end{array}$ & $\begin{array}{l}\text { two- } \\
\text { thirds of } \\
\text { what } \\
\text { he left }\end{array}$ & $\begin{array}{l}\text { they } \\
\text { will } \\
\text { have }\end{array}$ & $\begin{array}{l}\text { women } \\
\text { over two }\end{array}$ & $\begin{array}{l}\text { if } \\
\text { they } \\
\text { were }\end{array}$ & - & - & - & - & \\
\hline 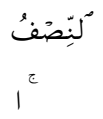 & فَلَهَا & كَكَنَتُوَإِن & - & - & - & - & - & - & - & - & \\
\hline $\begin{array}{l}\text { the } \\
\text { half }\end{array}$ & $\begin{array}{l}\text { she } \\
\text { will } \\
\text { have }\end{array}$ & $\begin{array}{l}\text { if she } \\
\text { was one }\end{array}$ & - & - & - & - & - & - & - & - & \\
\hline
\end{tabular}

According to H. G. Widdowson (2005), when elements combine with others along a horizontal dimension, they enter into what is known as a syntagmatic relationship, and elements, which have the same potential appearance in the same environment, are said to be in a paradigmatic relationship. (p. 33).

Many of the most authentic exegeses, such as Ibn Katheer (D. 774 H.), Al-Qurtuby (D. 671 H.), and Al-Fakhr Al-Razy (544-606 H.) argue

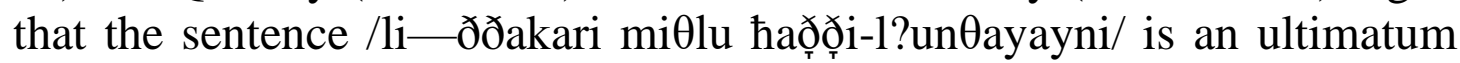
case of distributing the wealth after one's death, as the portion of the male is as twice as the portion of the female, or the portion of the female is the one-half of the portion of the male, where they consider them the same. Yet, the researcher discusses this issue in a different linguistic way, providing a parallel point of view.

Applied to the verse, along the horizontal dimension of sentences at analysis, the structure has syntagmatic elements in combination. Along the vertical dimension (shown through the vertical axes $\mathrm{A}, \mathrm{B}$, and $\mathrm{C}$ ), the 


\section{Translations; Y. Ali (1979) and M. Haleem (2004): An Appraisal Study}

structure has paradigmatic elements in association. In this respect, the phrase /?aððakar/ (i.e. 'the male') as a main constituent of the syntagmatic relation of the sentence 'for the male is like luck of the two females' is not skipped out of the context, while presuming the paradigmatic relation. The paradigmatic relation goes vertically; ascendantly to clarify the portion of 'if they were women over two', and descendantly to clarify the portion of 'if she was one', illustrating to whom the rest of portions will go. The difference between the axe A, and the axes $\mathrm{B}$ and $\mathrm{C}$ is the difference between overt and covert, where the word /?a-ððakar/ (i.e. 'the male') is overt in the first sentence /li-ððakari

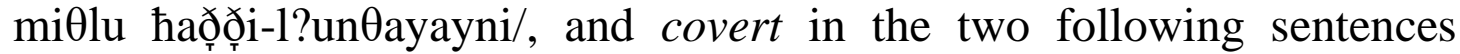
/fa? in kunna fawqa-Onatayni falahunna $\theta$ ulu $\theta \bar{a}$ mā taraka/ and /wa?in kānat wāhidatan falaha-nnişfu/ as they (i.e. /?a-ððakar/, /?al?unOayayn/, /nisā?an/ and /wāhidah/) are the offspring of the very addressee. The subordination occurs in the two later sentences 'if they were women over two, they will have two-thirds of what he left', and 'if she was one, she will have the half', shows that the former is already included in the same syntagm, and no need to be mentioned occasionally; otherwise, a sort of meaning redundancy will be occurred.

Hence, the sentence 'for the male is like luck of the two females', simultaneously, co-occurs with the following two sentences, as they are in the same syntagm, and in the same paradigm. Illustrating the point, syntactically, as it is mentioned in 3.2.3.2, the pronoun 'the women $N$ ' (نون النسوة) attached to the verb /kunna/ (i.e. 'they were'), is a pregnant phor acts as a multi-referential one. It is, simultaneously, an anaphoriccataphoric reference. Anaphorically, it refers to the previous antecedent /?al? untayayni/ (i.e. 'the two females'), and cataphorically, it refers to the following antecedent /nisāa an/ (i.e. 'women'). The researcher would like to provide a new coinage so-called cohesently, gathering between cohesively and coherently to illustrate the point. Therefore, the context, cohesently, transfers from the stance of life to the stance of death, in order to distinguish between what is option (i.e. 'the bequest'), and what is obligation (i.e. 'the inheritance'), showing how money could be distributed in both; otherwise, where could one find how to distribute one's wealth during his span of life along The Holy Text?

Of the rest of verse no. (4/11), the researcher agrees the current interpretation of the most exegeses.

\subsection{Transcendentalism}

Transcendentalism is a philosophy of great effect, that ascends to be a trend in the late $18^{\text {th }}$ century and $19^{\text {th }}$ centuries. It is relied much on 


\section{Dr. Khaled Nagib El-Sebaie Khalifa}

the belief that knowledge is neither excluded in experience nor observation. It opposes, thereby, the experimental philosophy which says that knowledge is springing from experience. According to the philosophy of Transcendentalism, the solution of human problems implies in the free enhancement of the individual's emotions, and truth implies only in the world of spirit.

What man observes in the natural world is nothing but reflections of the world of spirit. People attain their knowledge of the natural world through their senses and apprehension, but they attain their knowledge of the world of spirit through another force the so-called 'mind'. 'Mind' is defined by the Transcendentalists as 'the realizing independent ability of what is real in a free way.' The elements of Transcendentalism in the modern platonic philosophy that belong to ancient Greece, are derived from A. Kant's (1787) Critic of the Pure Reason (نقد العقل الحضض). This movement begins among the Unitarians in the United States as a philosophical, literary, religious, and social one. It gets its summit in the forties of the $19^{\text {th }}$ century headed by R. W. Emerson $(1803-1882)$. In his opinion, the natural world services the human, and provides him the ability to realize aesthetics around him. Emerson believes that people should attain knowledge through observation and reason. (Summarized and paraphrased from the Translation by Musa Wahba (1941-2017), of A. Kant's Critic of the Pure Reason, pp. 85-105.).

Noteworthy, employing Transcendentalism, the researcher prefers to explore new conceptions, connotations, interpretations, and to set a group of answerless questions in order to justify a new parallel view, of how to deal linguistically with the glorious Qur'an as an ideal pattern should be applied among Muslim people, compared to the ancient one.

From a Transcendentalist point of view, the researcher attempts to take a bold step to intensify the notion of the phrase /yūşîkumu-llāhu fi

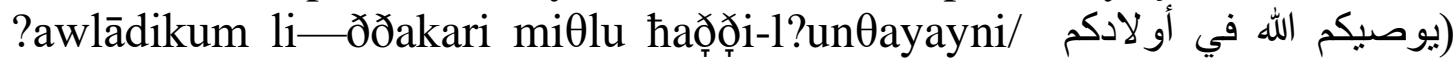
as it is not an inheritance case, but it is a case of distributing one's wealth during his lifetime, the issue of the phrase/fa?in kunna nisā?an fawqa-Onatayni falahunna $\theta u l u \theta a ̄$ mā taraka فإن كن نساء فوق) اثتتين فلهن ثلثا ما ترك), that immediately follows, as it expresses the exceptions of inheritance cases, and the issue of the phrase /wa? in kānat wāhidatan falaha-nnişfu/ (و إن كانت واحدة فلها النصف) as it considers that the paternal uncle is of no right to share the apparent heirs their belongings. Hence he is excluded (محجوب) from being an apparent heir. That is to say, the verse wholly, includes both; distributing one's wealth in life and death, only within the family blood line exclusively.

Based on the technique of Transcendentalism, the researcher would like to consolidate his opinion with the usage of verse (4/82). 


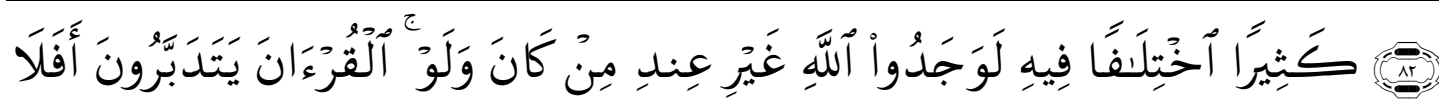

$(4 / 82)$

/?afalā yatadabbarūna-lqurān walaw kāna min ל̧indi yayri-llāhi awajadū fîhi-xtlāfan ka $\theta \overline{1} r \bar{a} /$

علي 24 محمد: \}ودلت هذه الآية، وقوله تعالي: (أفلا يتدبرون القرءان أم علي قلوب أقفالها)

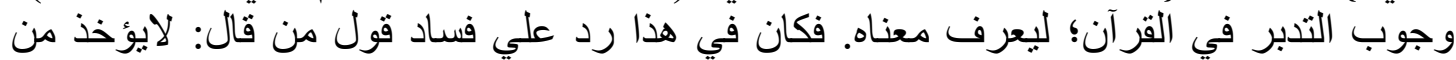

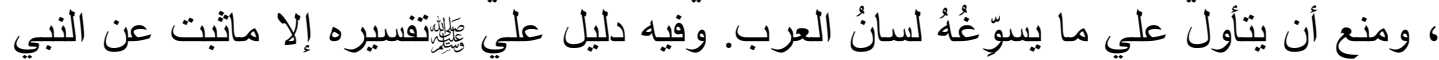
Qurtuby’s exgese (2006, p. 477)

\subsection{Life and Death}

The researcher would like to admit a number of Arabic resources which may consolidate his point of view.

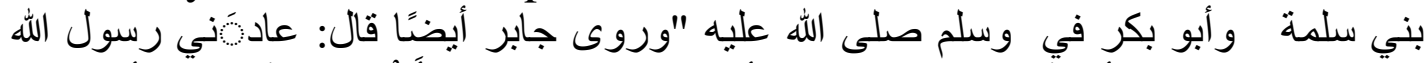

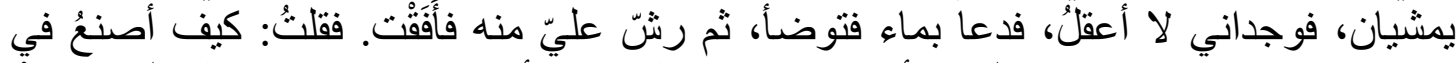

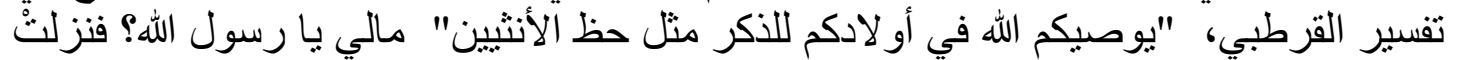
المجلد الثالث، ص 55، طبعة المكتبة التوفيقية.

"Gaber has narrated: The messenger of God - peace be upon Him - and Abu Bakar have visited me when I was ill, while they were walking in Bany Salamah, and they found me confused, and He asked for water and abluted, and He sprays some of the ablution water on me, then I awoke, I said: Oh Messenger of God, how do I in my treasure? Then the verse has been fallen down "Concerning your offspring, God bequeaths you, for the male is like the fortune of the two females" /yuşîkumu-llāhu

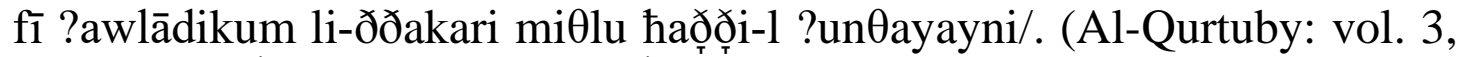
p. 55). "يوصيكم الله في أو لادكم للذ كر مثل حظ الأنثيين "

The researcher sees that the dialogue which occurred between Gaber and The Messenger (PBUH) refers to that, Gaber has to do the action of distributing his treasure while he is still alive not after death, otherwise, how did Gaber feel confusion due to his treasure, if he was already dead?

This clarifies that the phrase "for the male is like fortune of the two females" is not an inheritance case, but a case of distributing one's treasure for his offspring during his life not after death.

: قول الله تعالى "يوصيكم الله في الر ابعة ـ قوله تعالى : "يوصيكم الله في أو لادكم" قالت الثافعية

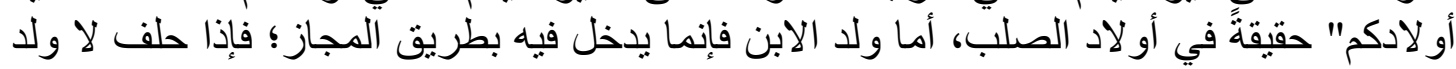
لله، وله ابن لم يحنث.

Forth, Shafaians (الشافعية) say that the phrase "يوصيكم الله في أولادكم" "Concerning your offspring, God bequeaths you" /yuşīkumu-llāhu fī ?awlādikum/ is actually for offspring, but the grandson is, metaphorically, 


\section{Dr. Khaled Nagib El-Sebaie Khalifa}

maintained within the immediate son. If a man swears at he has no son while he has a grandson, then he does not lie. (Al-Qurtuby: vol. 3, p. 56). In his exegesis, Al-Razy says:

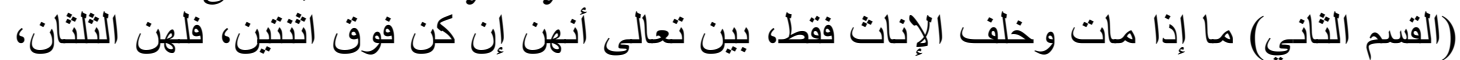

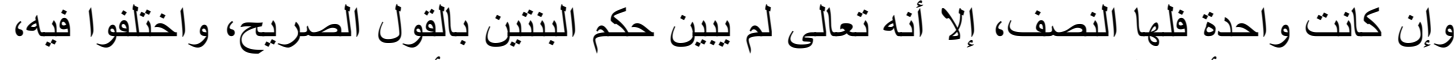

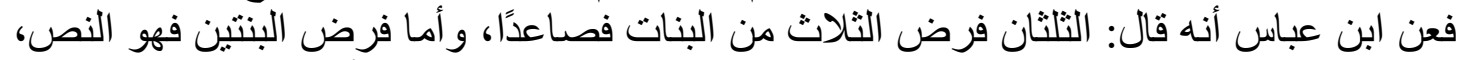

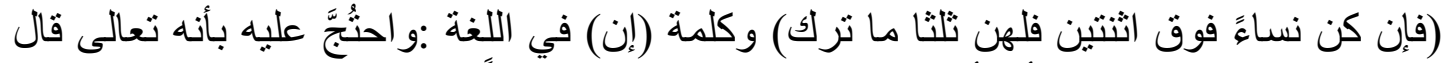

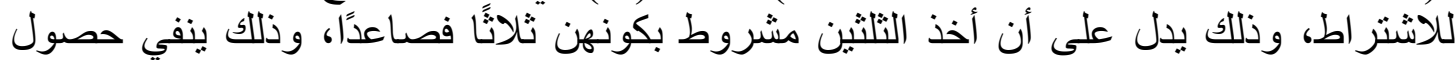
الثلثين للبنتين. الفخر الرازي. الجزء التاسع، ص 212. دان دار الفكر للطباعة و النشر و التوزيع.

Second section, in case that the deceased person has left only females, God clarifies that if they were above two females, they will have the two-thirds of what he left, and if she was only one, she will have the half of what he left. Yet, God does not explicitly clarify the ordinance of the two daughters. The interpreters were confused about this. Iben Abbas said: the two-thirds is the ordinance of the three daughters and above, but the half is the ordinance of the two daughters. Iben Abbas has been protested by others, as The Lord said: "If they were women above two, they will have the two-thirds of what he left". /fa?in kunna nisā?an

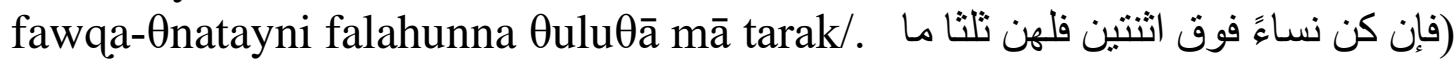
(ترك. The subordinator If is a conditional one, that is to say, that having the two-thirds is provided by being three women daughters and upward (above), which, in turn, negates having the two-thirds for the two daughters or upward (above). (Al-Razy: vol, 9, p. 212).

The thesaurus of The Congregation of the Arabic Language 1990, The Holy Qur'an Segments Thesaurus, presents some definitions of the singular and the plural form of the segment offspring /walad/ (ولد) as follows:

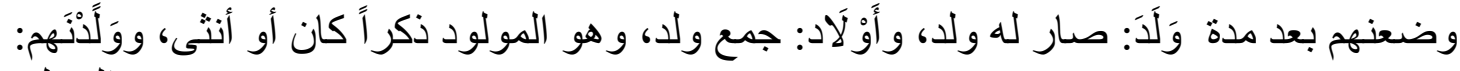

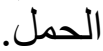

(The Holy Qur'an Segments Thesaurus (1990). vol. 2, p. 501).

It also presents some definitions of the singular and the plural form of the segment male /Jakar/ (ذكر) as follows:

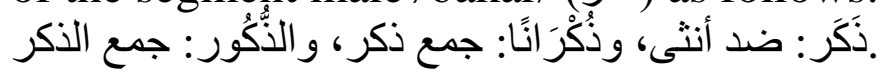

The Holy Qur'an Segments Thesaurus (1990). vol. 2, pp. 438-39.

The definitions assert that the segment male is antonymous to female. That is to say, there is a considerable difference between the two concepts: a) gender, and b) attribution.

2.6. Competence and Performance.

According to Chomsky (1965), Competence is the system of linguistic knowledge possessed by native speakers of a language. It is distinguished from linguistic performance, which is the way a language competence system is used in communication. He introduced this 
concept in his elaboration of generative grammar, where it has been widely adopted and competence is the only level of language that is studied. Competence is the ideal language system that enables speakers to produce and understand an infinite number of sentences in their language, and to distinguish grammatical sentences from ungrammatical sentences. This is unaffected by "grammatically irrelevant conditions" such as speech errors. Chomsky differentiates competence, which is an idealized capacity, from performance being the production of actual utterances.

According to him, competence is the ideal speaker-hearer's knowledge of his or her language and it is the 'mental reality', which is responsible for all those aspects of language use, which can be characterized as linguistic.

Clarifying the real difference between competence and performance, Chomsky separates competence and performance; he describes competence as an idealized capacity that is located as a psychological or mental property or function, and performance as the production of actual utterances. In short, 'competence involves knowing' the language, and 'performance involves doing something' with the language. The difficulty with this construct is that it is very difficult to assess competence without assessing performance. In this respect, Chomsky (1965) distinguishes between competence and performance saying:

We thus make a fundamental distinction between competence (the speaker-hearer's knowledge of his language) and performance (the actual use of language in concrete situations). Observed use of language (...) may provide evidence as to the nature of this mental reality, but surely cannot constitute the actual subject matter of linguistics, if this is to be a serious discipline."( 1965, p. 4)

Newby, D. (2012) asserts:

A record of natural speech will show numerous false starts, deviations from rules, changes of plan in mid-course, and so on. The problem for the linguist, as well as for the child learning the language, is to determine from the data of performance the underlying system of rules that has been mastered by the speaker-hearer and that he puts to use in actual performance. In this, the difference between both could be said as: 'Performance is the way to judge Competence'. (p .15)

Chomsky's point of view of competence and performance is perfectly applied to the verse: 


\section{Dr. Khaled Nagib El-Sebaie Khalifa}

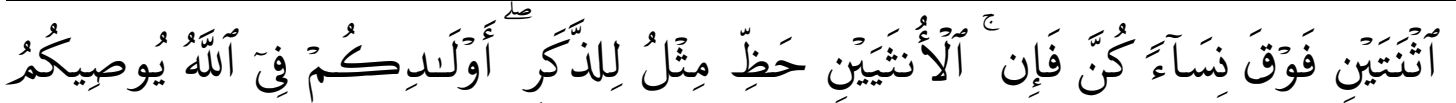

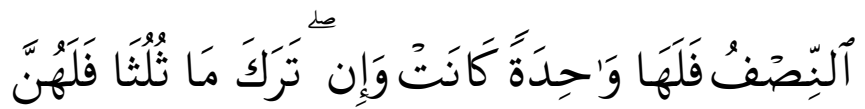

Ali and Haleem translate /?awlādikum/ as children and /nisā?an/ as daughters, where no equivalence between ST and TT, and Monoglossia replaces Heteroglossia, which results a clear deviation in the form, function, and meaning.

This reflects lack of competence as an authentic translation from the part of two translators, and intensifies the performance as a cultural translation. According to Newmark (1984,p. 42, 1988, p. 48), he states that cultural translation (monoglossic) may be inferior to the original, since it involves loss of meaning (the force of massage), whereas authentic translation (heteroglossic) may be better as it gains force and clarity what nit loses in semantic content.

Table 5: Features of Cultural Translation and Authentic Translation

\begin{tabular}{|l|l|l|}
\hline$\#$ & Cultural translation & Authentic Translation \\
\hline 1 & Monoglossic. & Heteroglossic \\
\hline 2 & Translator-based. & Text-language-based \\
\hline 3 & $\begin{array}{l}\text { Pursues translator's thought } \\
\text { process. }\end{array}$ & Pursues translator's intention. \\
\hline 4 & Related to thoughts. author as & $\begin{array}{l}\text { Related to text. } \\
\text { cultural content of original text } \\
\text { accessible to reader. }\end{array}$ \\
\hline 5 & $\begin{array}{l}\text { Concerned with } \\
\text { individual. }\end{array}$ & Semantic-and-syntactic-oriented. \\
\hline 6 & Effect-oriented. & Bound/Literal Translation. \\
\hline 8 & Free translation. & Informative. \\
\hline 9 & $\begin{array}{l}\text { Effective. } \\
\text { simpler, clearer, more direct, } \\
\text { superficial, } \\
\text { conforming to particular register } \\
\text { of language, but longer. }\end{array}$ & $\begin{array}{l}\text { Usually more awkward, more } \\
\text { detailed, difficulty credible, more } \\
\text { complex, deeper, but briefer. }\end{array}$ \\
\hline 10 & Social. & Textual. \\
\hline 11 & Target-language based & Source-language based \\
\hline 12 & $\begin{array}{l}\text { Less powerful } \\
\text { Translator has the right to correct } \\
\text { and to improve the logic and } \\
\text { style of the original, clarifies } \\
\text { ambiguities, jargons, normalize }\end{array}$ & $\begin{array}{l}\text { Translator has no right to adapt, to } \\
\text { improve, or to correct. }\end{array}$ \\
\hline
\end{tabular}


Inheritance Rules in Surat Al-Nisa' (Women) as a Contemporary Reading of Two

Translations; Y. Ali (1979) and M. Haleem (2004): An Appraisal Study

\begin{tabular}{|l|l|l|}
\hline & bizarre personal usage. & \\
\hline 14 & $\begin{array}{l}\text { May improve the original to gain } \\
\text { force and clarity, despite loss in } \\
\text { semantic content. }\end{array}$ & $\begin{array}{l}\text { Always inferior to the original } \\
\text { because of loss of meaning. }\end{array}$ \\
\hline 15 & $\begin{array}{l}\text { Ephemeral and temporal } \\
16\end{array}$ & $\begin{array}{l}\text { Eut of time and local places } \\
\text { "eternal". }\end{array}$ \\
\hline $\begin{array}{l}\text { synonymy, provided the facts are } \\
\text { impressed. }\end{array}$ & Inaccuracy is always wrong. \\
\hline 18 & $\begin{array}{l}\text { Fulfils one particular function. } \\
\text { (i.e. a successful act). }\end{array}$ & Wide and universal. \\
\hline 19 & $\begin{array}{l}\text { Sometimes a product of a } \\
\text { translation team. }\end{array}$ & $\begin{array}{l}\text { Target: a "true" version, (i.e. an } \\
\text { exact statement). }\end{array}$ \\
\hline 20 & $\begin{array}{l}\text { Basically the work of translating a work of one indiviual } \\
\text { translator. } \\
\text { is a craft. }\end{array}$ & $\begin{array}{l}\text { Basically the work of translating } \\
\text { is a science. }\end{array}$ \\
\hline 21 & Gives message & Gives meaning. \\
\hline
\end{tabular}

\subsection{Authorial ( $\left(^{\text {st }}\right.$ Person $) \quad$ vs. Non-Authorial $\left(2^{\text {nd }} \& 3^{\text {rd }}\right.$ Person $)$ Affect}

Authorial ( $1^{\text {st }}$ Person) and non-Authorial $\left(2^{\text {nd }} \& 3^{\text {rd }}\right.$ Person $)$ Affect, together as a technique, is an evaluative one whereby the reader can provide a canonical assessment to identify instances of authorial Affect and non-authorial Affect. Martin (1997) theorizes in a great detail, to what extent and how this technique could be employed analyzing the affectual choices. According to him, Martin illustrates:

The most obvious rhetorical function of such a use of Affect is to indicate an attitudinal position towards person or thing or situation which triggers the emotion. Phenomena which trigger positive emotions are to be viewed positively, and phenomena which trigger negative emotions are to be viewed negatively. But, the rhetorical functionality of such meanings is rather more complicated than this. Such emotional assessments reside entirely in the individual subjectivity of the speaker/writer. It is an entirely personalised and individualised mode of evaluation and various rhetorical consequences follow from this. Through such 'authorial Affect', the speaker/writer strongly foregrounds one's subjective presence in the communicative process. Through this revelation of emotional response, one seeks to establish an interpersonal rapport with the reader in the sense that, for the evaluation to carry any rhetorical weight, the 


\section{Dr. Khaled Nagib El-Sebaie Khalifa}

reader must see this personalised response as in some way relevant, significant, valid, justified, or at least understandable. Thus, by the use of such Affect, the writer bids to establish an interpersonal bond with the reader to the extent that the reader agrees with, understands, or at least sympathizes with that emotional reaction. The writer is the source of the emotion by which the evaluation is conveyed and hence takes some responsibility for that evaluation. But we also need to consider instances where it is not the author's emotions which are described but those of other human individuals.

The sub-title, 1.8., involves the writer/speaker indicating how they have responded emotionally to person, thing, happening, or situation being evaluated. Obviously they thereby undertake responsibility for that attitudinal value assessment. The researcher sees that such technique has a considerable value in analyzing the phrase

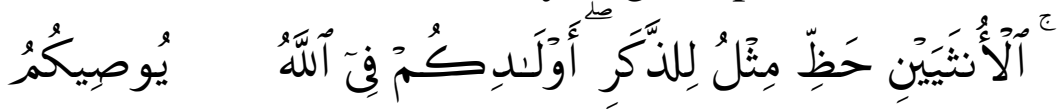

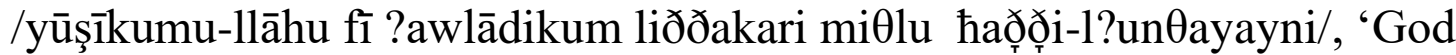
bequeaths you, concerning your offspring, for the male is like the fortune of the two females'. (The researcher's translation). The phrase /yūşīkumu-llāhu/, as for the $2^{\text {nd }}$ and $3^{\text {rd }}$ person, is an affectual value, as it, simultaneously, includes feelings of satisfaction for the males and dissatisfaction for the females, or at least it implies an inner conflict resulting the interrogation, 'why so?'.

Rhetorically, the attributed evaluator (i.e. 'God') acts as if He is a surrogate, so to speak, for the non-authorial (i.e. 'people'), but He offers them a bequest neither wrapped in an obligative performative action nor in an imperative form, with neither cue phrases nor signalling phrases, referring to that it is an inheritance case, but it, implicitly, asserts that it is a case of distributing one's wealth while he is still alive. This is because the style of the phrase is a discursive one, and there is no any discursive style could be delivered to a deceased person.

Under the title Clause: Types of Exchange, Speech Functions and Grammatical Mood and the sub-title Exchanges writes N. Fairelough (2004, pp. 106-109): An 'exchange' is a sequence of two or more conversational 'turns' or 'moves' with alternating speakers, where the occurrence of move I leads to the expectation of move 2. Fairclough distinguishes two main categories of expectation of exchange, activity exchange (often oriented to non-textual action) and knowledge exchange, where the later is inserted within the former, and the former is delayed to the completion of the later. Activity exchange is doing things, or getting things done, rather than (just) saying thing. 
Applied to the phrase /yūşīkumu-llāhu fì ?awlādikum liððakari

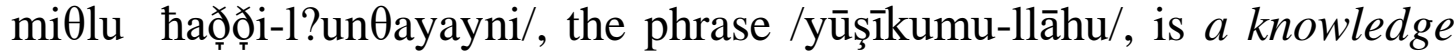
exchange by the Addressor/Authorial (i.e. 'God'), and the phrase

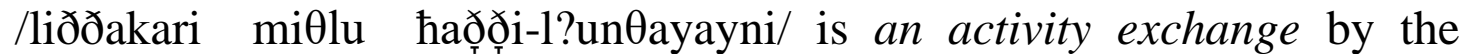
addressee/non-authorial (i.e. 'people who are aware of God's command'), in which it must be done/obeyed by them, and not by anyone else.

According to Stageberg, N. C. (1965, p. 184), the same phrase patronizes pattern \# 6 of the English sentence as follows: $(\mathrm{N} 1+\operatorname{TrV}+\mathrm{N} 2$ $+\mathrm{N} 3$ ), which functionally, $\mathrm{N} 1$ indicates the subject, $\mathrm{TrV}$ indicates the transitive verb, $\mathrm{N} 2$ indicates IO/indirect object, and N3 indicates DO/the direct object. In this, the phrase is a mere Verbal Declarative Sentence (VDS).

According to Baker's (1992) Thematic Structure Theory in Translation, we could compare nominalization and verbal forms in the theme position. Like Brazilian Portuguese, and Spanish, is Arabic language, which Baker calls (verb-inflected languages). These languages often place the verb in the first or 'theme' position/slot. The mentioned phrase consists of five main constituents starting in: 1) TrV يوصي/yūşī/. 2) $\mathrm{N} 2 / \mathrm{IO}$ the $2^{\text {nd }}$ person pronoun $/ \mathrm{kum} /$. 3 ) NI/subject /?allāhu/. 4) pp /fi? awladikum/ (the recipient in the semantic role), 5) N3/DO (noun clause/declarative sentence). A transposition has occurred, where rheme transposes theme. As a logical result, neither N1 nor N2 nor N3 are dead. As the non- authorial $/ 2^{\text {nd }}$ person is already the addressee, how come the non- authorial who is the deceased person, in this case, could be addressed as a one of the two interactants of the discourse, unless he is actually alive? The researcher asks!

\subsection{Simile}

\subsubsection{Definition of Simile}

'Figurative language is of great value. It adds clearness to our speech; it gives it more force; or it imparts to literature beauty.' (Webster, 1900, p. 258).

Beardsley (1950) introduces the distinction by distinguishing between 'closed' and 'open' simile. In a closed simile such as 'Your smile is precious as a jewel.', the scope is narrowed, as it is explicitly stated the respect in which the compared elements are similar or not. On the contrary, in an open simile like 'Your smile ia as a jewel.' One must resort to the context, world knowledge and cultural background to be able to guess the source of the comparison.

In their book, The Routledge Dictionary of Literary Terms, Peter Childs, and Roger Fowler (2006) define: Simile is a comparison, 


\section{Dr. Khaled Nagib El-Sebaie Khalifa}

discursive, tentative, in which the 'like' or 'as . . . as' suggests, from the viewpoint of reason, separateness of the compared items. Because simile is usually a pointedly rationalized perception, it has none of the revelatory suddenness of metaphor nor expresses and demands the same degree of mental commitment to the image. Instead, it presents itself as a provisional, even optional, aid whose function is explanatory or illustrative. Simile appeals to what we already know about things, metaphor invites the imagination to break new ground; for this reason, we can pass an evaluative judgement on simile, whereas we must either take or leave a metaphor. (pp. 218-219).

In Britannica, Simile is a figure of speech involving a comparison between two unlike entities. In simile, unlike the metaphor, the resemblance is explicitly indicated by the words 'like' or 'as'. The common heritage of simile in everyday speech usually reflects simple comparisons based on the natural world or familiar domestic objects, as in "He eats like a bird," "He is as smart as a whip," or "He is as slow as molasses." In some cases the original aptness of the comparison is lost, as in the expression "dead as a doornail." A simile in literature may be specific and direct or more lengthy and complex.

https://www.britannica.com/art/simile.

As well, Beardsley (1950) introduces the distinction by distinguishing between 'closed' and 'open' simile. In a closed simile such as 'Your smile is precious as a jewel.', the scope is narrowed, as it is explicitly stated the respect in which the compared elements are similar or not. On the contrary, in an open simile like 'Your smile ia as a jewel.' One must resort to the context, world knowledge and cultural background to be able to guess the source of the comparison.

\subsubsection{The Male vs The Two Females}

Rhetorically, according to Suzanne Mpouli (2016), the comparative sentence, such a simile, of course, has the canonical structure of the comparative construction. A simile and a literal comparison differ only in terms of semantics: a simile uses world knowledge to help deduce and picture specific features of an entity in relation to another entity which generally belongs to a different semantic domain while a comparison merely states whether two entities are equal or not. In addition, on the surface, a type of grammatical constructions, referred to as pseudocomparisons, has exactly the same syntactic structure as literal comparisons and consequently, similes. In fact, in some cases, markers of comparison convey an estimation 'approximation', highlight a function 'identification', introduce a hyponym 'exemplification' or coordinate terms 'coordination'. 
As so, the obvious resemblance occurred between tenor/source (i.e. 'the male') and the vehicle/target (i.e. 'the two females') of the verse

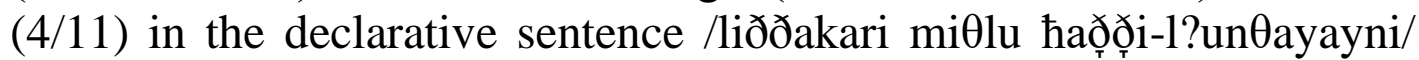

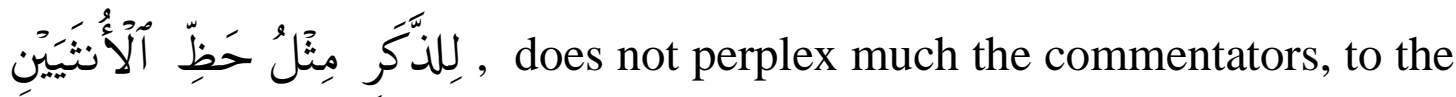
extent that they only pour their great interest out into the formula of (one = two) that clarifies, from their point of view, the priority of males to females. As the main elements of simile are four; tenor/source, comparing marker, vehicle/target, and respect (paraphrased, p. 90), these four elements have to be taken, rhetorically, into consideration, especially the most important one that conveys the qualities from tenor/source into vehicle/target, the comparing marker. In this respect, the researcher would like to set an example through a schedule, illustrating the point.

Table 6: Example of Simile.

\begin{tabular}{|c|c|c|c|c|}
\hline parameters & $\begin{array}{l}\text { tenor/so } \\
\text { urce }\end{array}$ & $\begin{array}{l}\text { comparing } \\
\text { marker }\end{array}$ & $\begin{array}{l}\text { vehicle/ta } \\
\text { rget }\end{array}$ & respect \\
\hline $\begin{array}{l}\text { Queen is like } \\
\text { the rose }\end{array}$ & Queen is & like & the rose & $\begin{array}{l}\text { Qualities of beauty, } \\
\text { softness, odour, } \\
\text { colouring, } \\
\text { cheerfulness, and } \\
\text { etc. }\end{array}$ \\
\hline 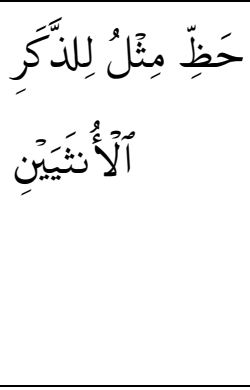 & لِلذََّّرَ & مِثُل & 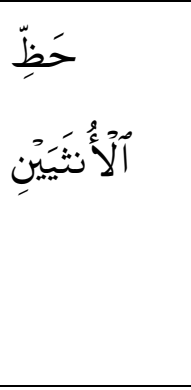 & $\begin{array}{l}\text { Like above, qualities } \\
\text { of amount, portion, } \\
\text { priority to choose } \\
\text { their portion first, } \\
\text { priority to leave what } \\
\text { they do not want } \\
\text { equal as twice as } \\
\text { they choose, and etc. }\end{array}$ \\
\hline 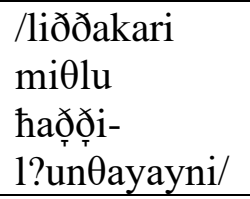 & $\begin{array}{l}\text { /liððakar } \\
\text { i/ }\end{array}$ & $/ \mathrm{mi} \theta \mathrm{lu} /$ & 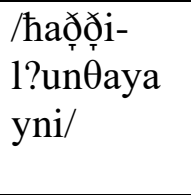 & $* * * * *$ \\
\hline
\end{tabular}

As the commentators almost skip the rhetorical main role of using the comparing marker $/ \mathrm{mi} \theta 1 /$ (i.e. 'like'), it appeals to the researcher to spot its vital semantic importance. The meaning resulted/inferred from such simile is that the respect, which implies the qualities, clearly

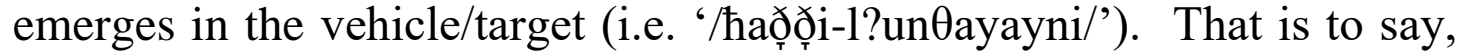
the base of distributing the begetter's wealth comes from determining the fortune of the two females first, and then, comes the fortune of the male as a canonical portion compared to them. Besides, the fortune of the male is not as perfectly as the fortune of the two females, but it is like or similar to. Finally, the two fortunes are alike, not perfect. 


\section{Dr. Khaled Nagib El-Sebaie Khalifa}

\subsection{Specimen of Distributing Inheritance (Suggested)}

On the basis of what has been mentioned under the title 4.4, Inheritance and its subtitles, the researcher would like to present a suggested specimen of distributing one's wealth in life and death, as a parallel debatable point of view. This specimen is based on eleven inferred parameters directly from the ST. These parameters are: 1) general cases of distribution, 2) beneficials, 3) basis of distribution, 4) case study of the beneficial, 5) case study of the deceased person, 6) the term of amount, whether luck or portion, 7) conditions of distribution, whether related to father, husband, wife or beneficials, 8) key word, 9) to whom the rest of the portion goes?, 10) verse; wording, transcription, and translation, 11) classification of portion, whether real or designated. The three main determiner inheritance verses are (4/12), (4/12), and (4/176).

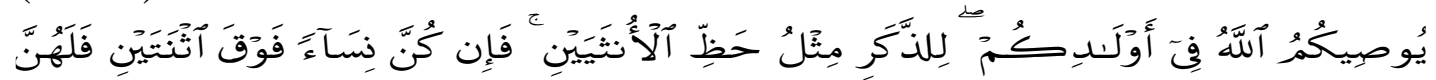

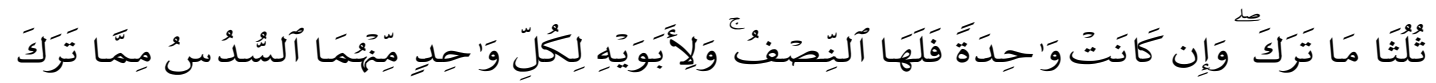

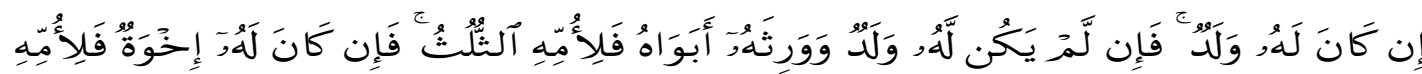

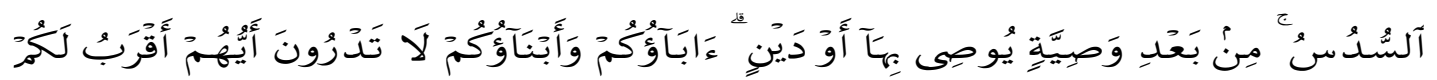

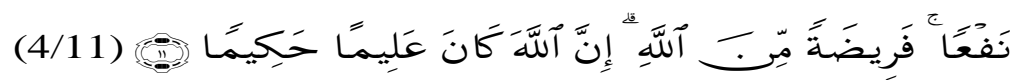

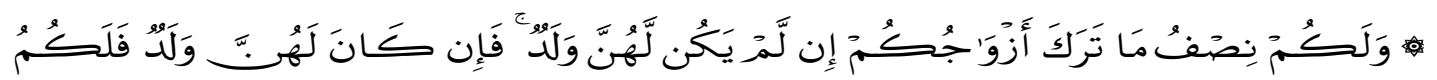

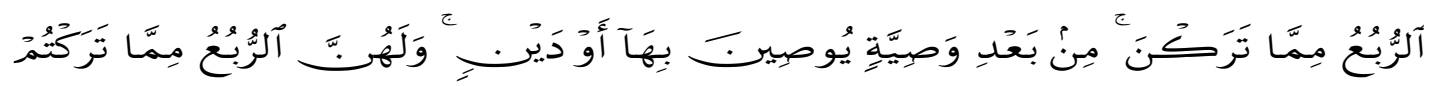

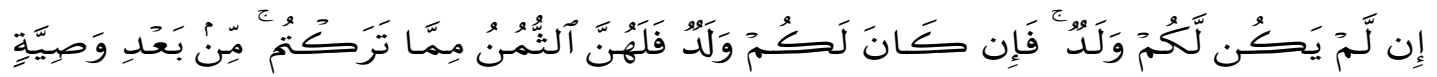

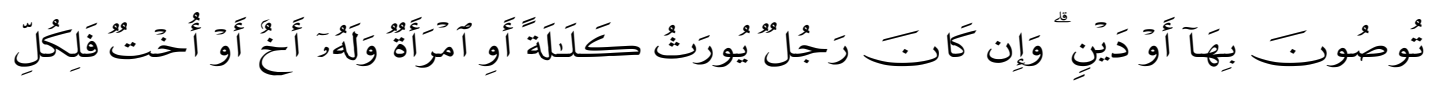

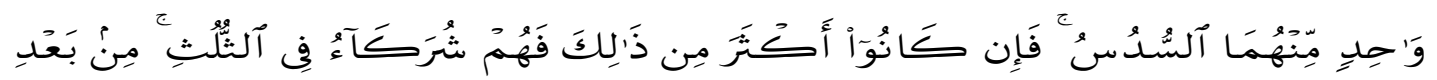

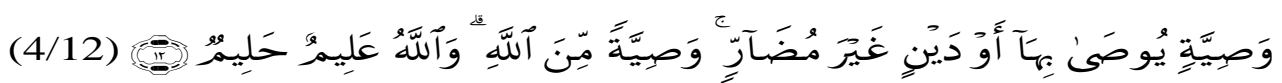

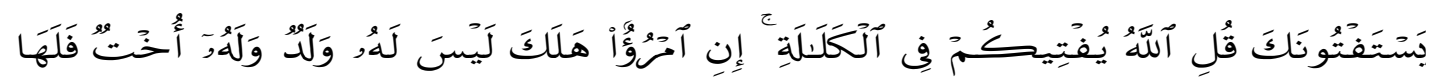

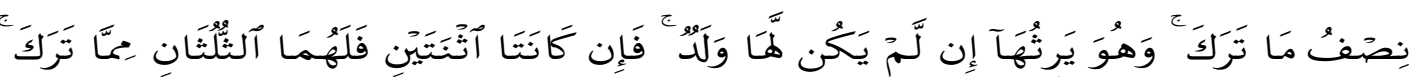

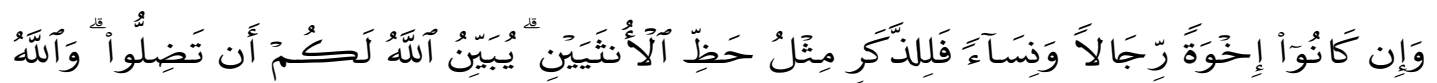

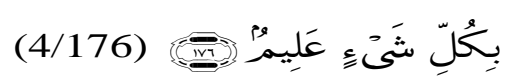

Just for studying purposes, once we divide these verses into definite syllables, then, we find sixteen distributing cases, as follows:

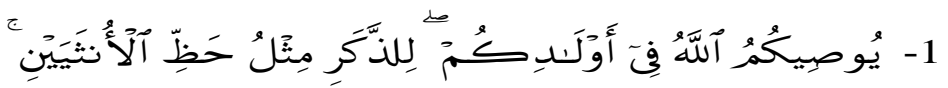


Inheritance Rules in Surat Al-Nisa' (Women) as a Contemporary Reading of Two Translations; Y. Ali (1979) and M. Haleem (2004): An Appraisal

Study

The highlighted constituents reflects the key words that refer to whether the case is inheritance one or a case of distributing one's wealth while still alive. Such division is illustrated in a schedule as an attempt to provide a parallel point of view of distributing one's wealth as follows:

Table 7: Suggested Specimen of Distributing One's Wealth in Life and Death.

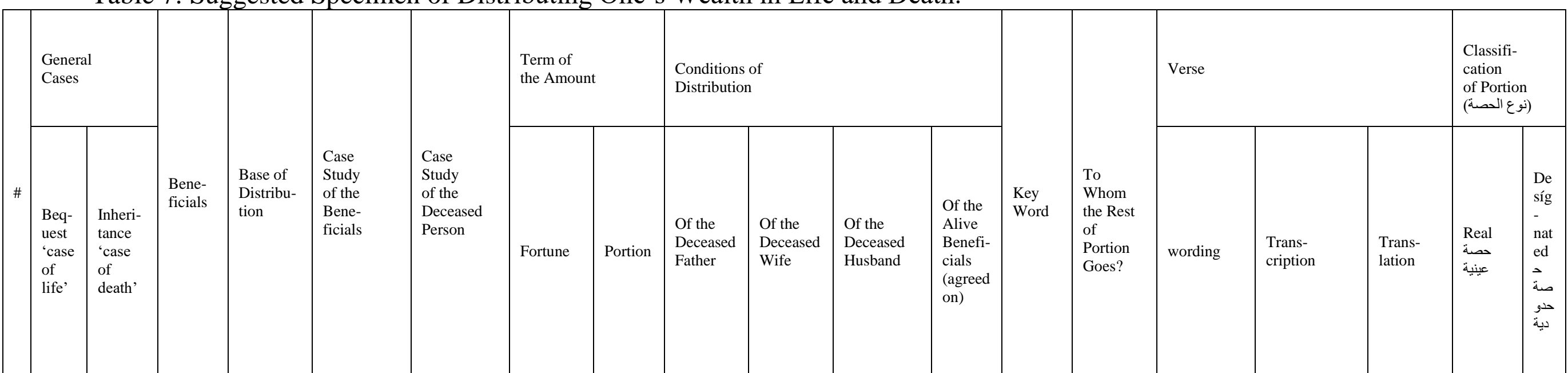




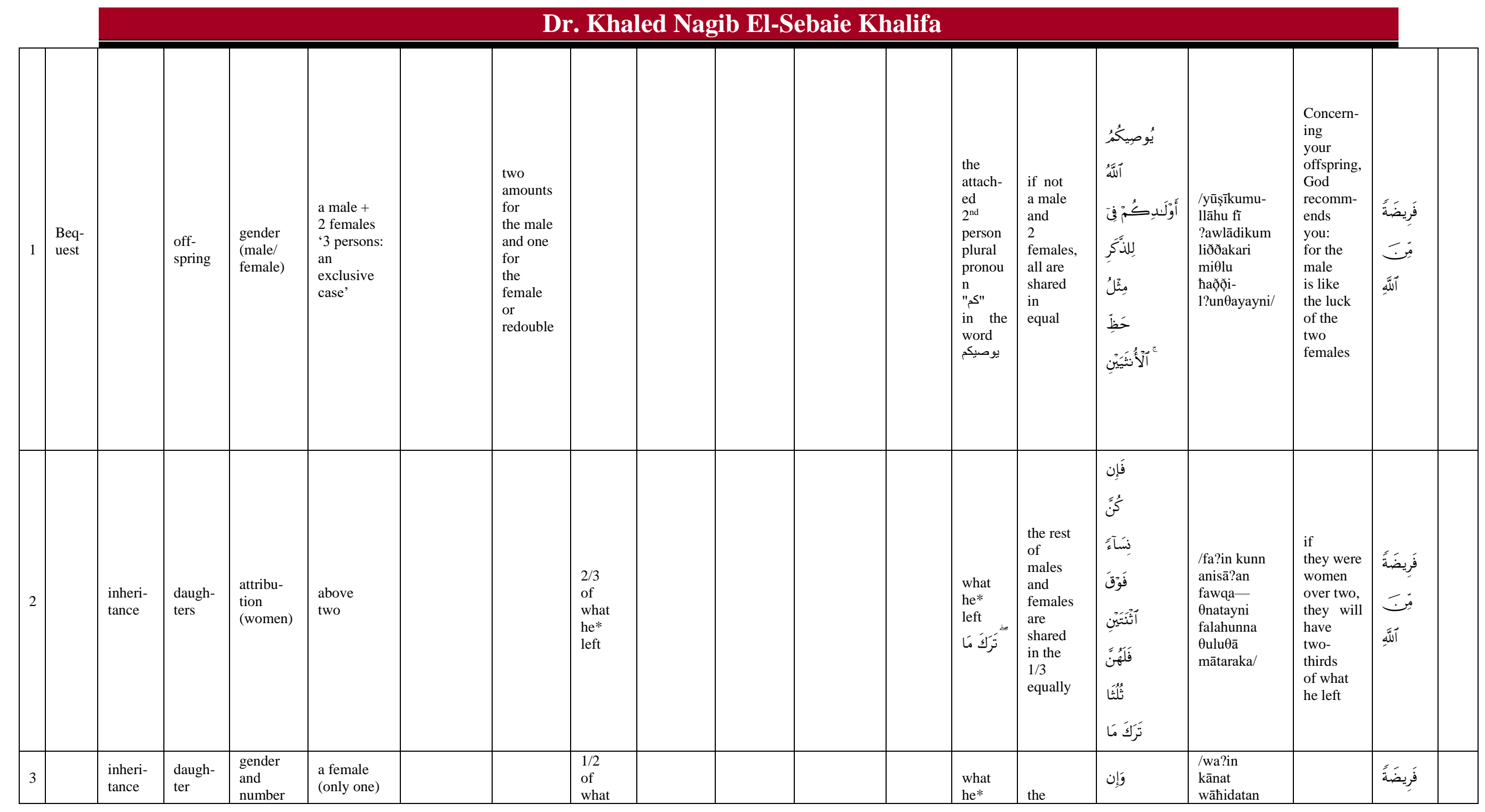


Inheritance Rules in Surat Al-Nisa' (Women) as a Contemporary Reading of Two Translations; Y. Ali (1979) and M. Haleem (2004): An Appraisal Study

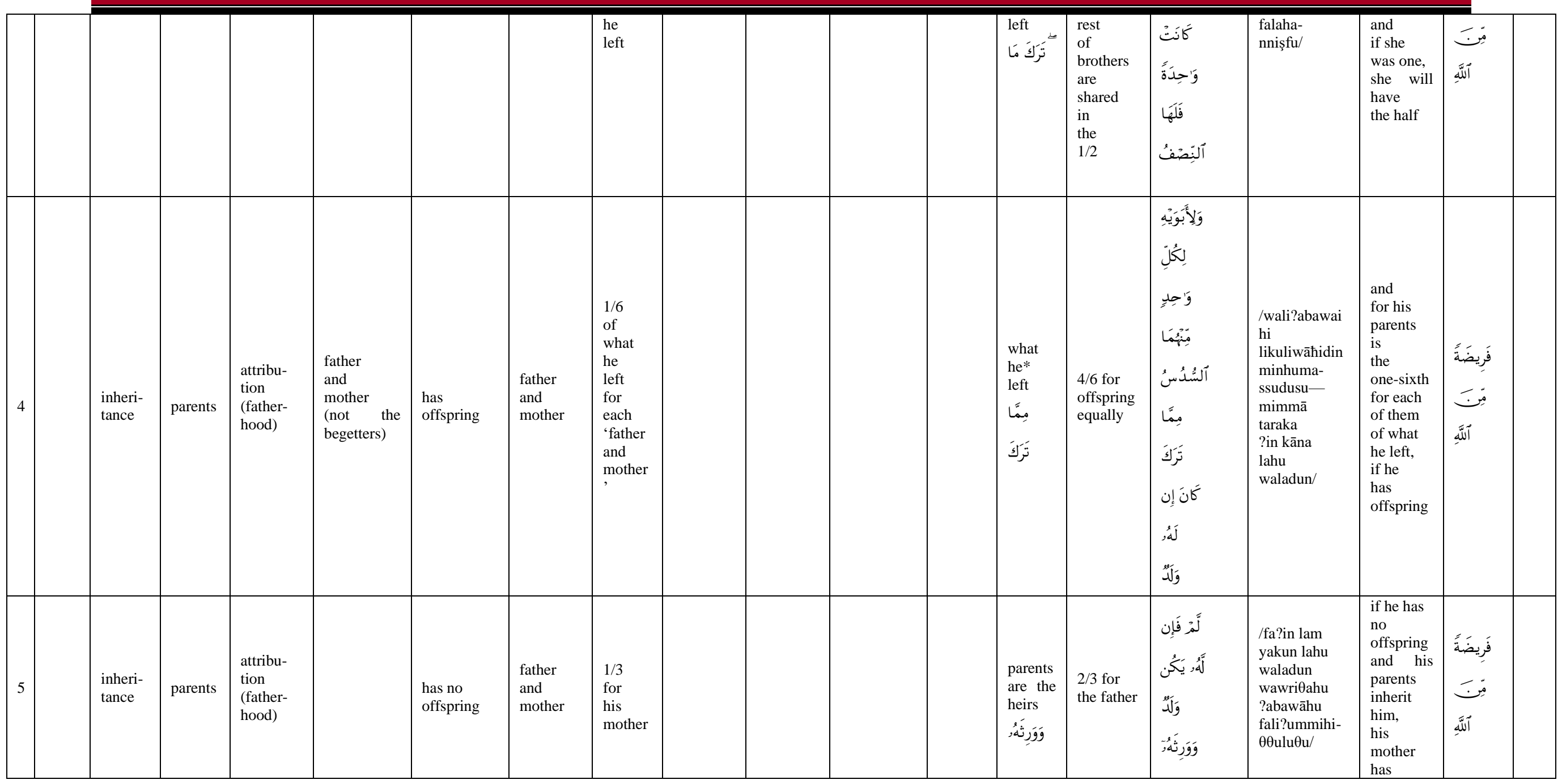




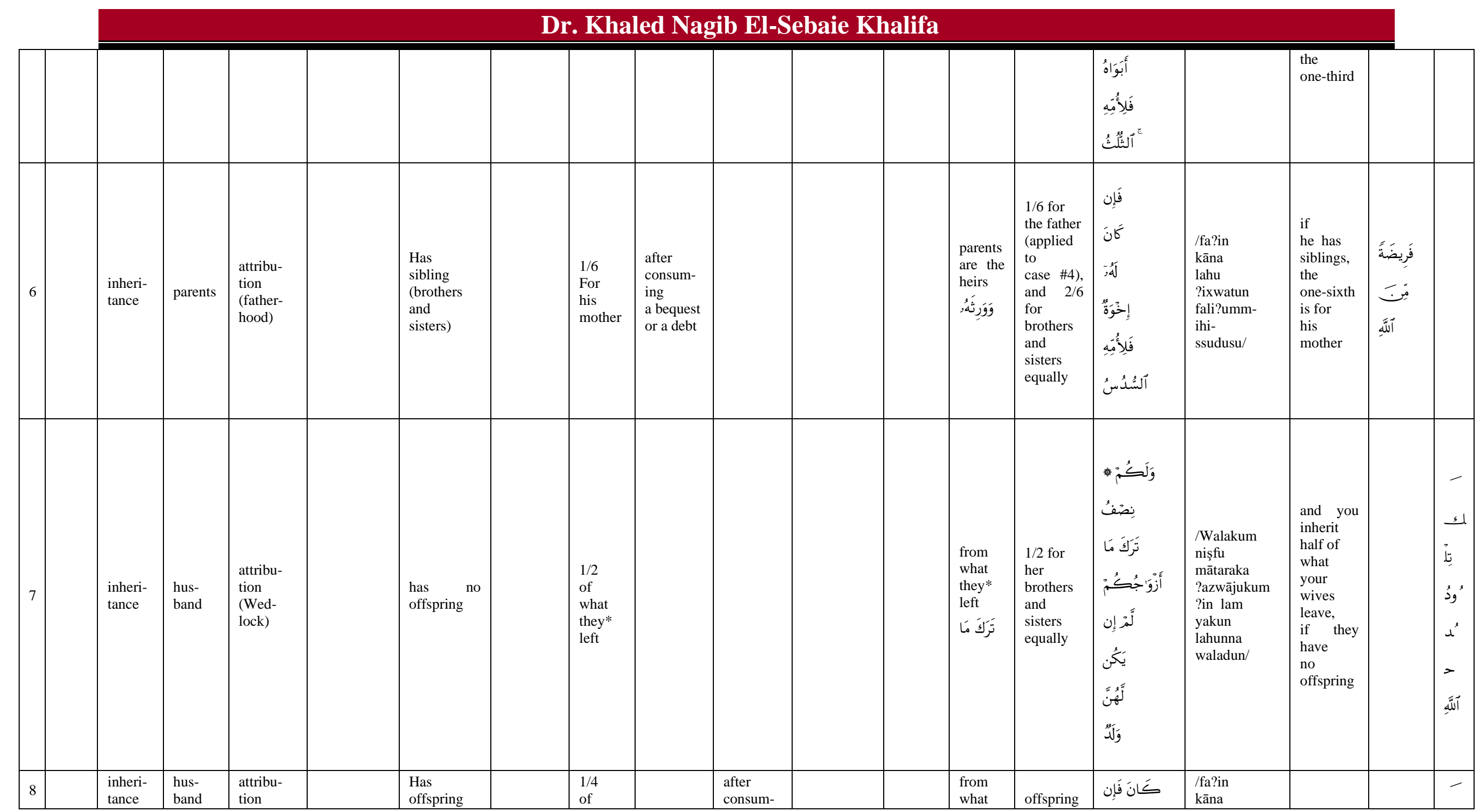


Inheritance Rules in Surat Al-Nisa' (Women) as a Contemporary Reading of Two Translations; Y. Ali (1979) and M. Haleem (2004): An Appraisal Study

\begin{tabular}{|c|c|c|c|c|c|c|c|c|c|c|c|c|c|}
\hline & & & $\begin{array}{l}\text { (wed- } \\
\text { lock) }\end{array}$ & & $\begin{array}{l}\text { what } \\
\text { they* } \\
\text { left }\end{array}$ & $\begin{array}{l}\text { ing } \\
\text { a bequest } \\
\text { or a debt }\end{array}$ & & $\begin{array}{l}\text { they* } \\
\text { left } \\
\text { تَرَكَنَنَ }\end{array}$ & $\begin{array}{l}\text { are } \\
\text { shared } \\
\text { in } \\
3 / 4 \\
\text { equally }\end{array}$ & 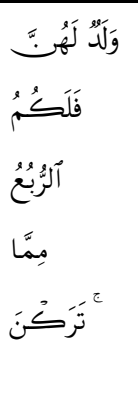 & $\begin{array}{l}\text { lahunna } \\
\text { waladun } \\
\text { falakumu- } \\
\text { rrubuל̌u } \\
\text { mimmā } \\
\text { tarakna/ }\end{array}$ & $\begin{array}{l}\text { if they } \\
\text { have } \\
\text { offspring, } \\
\text { you will } \\
\text { have } \\
\text { the } \\
\text { one- } \\
\text { fourth } \\
\text { of what } \\
\text { they } \\
\text { left }\end{array}$ & 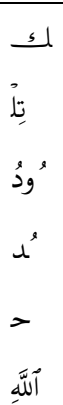 \\
\hline 9 & $\begin{array}{l}\text { inheri- } \\
\text { tance }\end{array}$ & wife & $\begin{array}{l}\text { attribu- } \\
\text { tion } \\
\text { (wed- } \\
\text { lock) }\end{array}$ & $\begin{array}{l}\text { has no } \\
\text { offspring }\end{array}$ & $\begin{array}{l}1 / 4 \\
\text { of } \\
\text { what } \\
\text { YOU* } \\
\text { left }\end{array}$ & & & 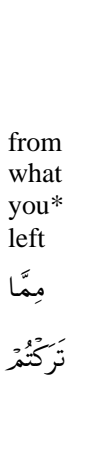 & $\begin{array}{l}3 / 4 \text { for } \\
\text { his } \\
\text { brothers } \\
\text { and } \\
\text { sisters } \\
\text { equally }\end{array}$ & 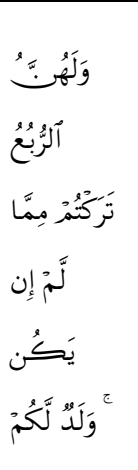 & 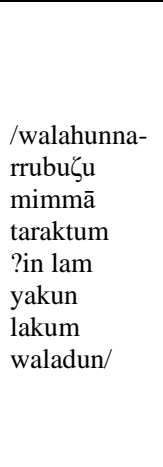 & $\begin{array}{l}\text { and they } \\
\text { will } \\
\text { have the } \\
\text { one- } \\
\text { fourth } \\
\text { of what } \\
\text { you left, } \\
\text { if you } \\
\text { have } \\
\text { offspring }\end{array}$ & 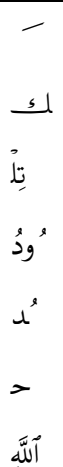 \\
\hline $\begin{array}{l}1 \\
0\end{array}$ & $\begin{array}{l}\text { inheri- } \\
\text { tance }\end{array}$ & wife & $\begin{array}{l}\text { attripu- } \\
\text { tion } \\
\text { (wed- } \\
\text { lock) }\end{array}$ & $\begin{array}{l}\text { Has } \\
\text { offspring }\end{array}$ & $\begin{array}{l}1 / 8 \\
\text { of } \\
\text { what } \\
\text { YOU* } \\
\text { Left }\end{array}$ & & $\begin{array}{l}\text { after } \\
\text { consuming } \\
\text { a bequest } \\
\text { or a debt }\end{array}$ & 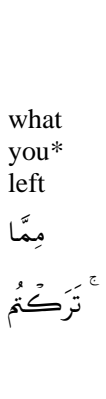 & $\begin{array}{l}\text { offspring } \\
\text { are } \\
\text { shared } \\
\text { in } \\
7 / 8 \\
\text { equally }\end{array}$ & 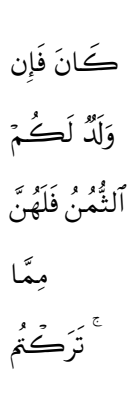 & 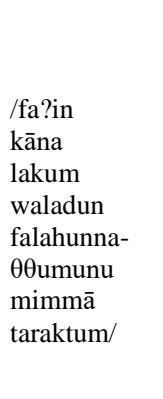 & $\begin{array}{l}\text { if you } \\
\text { have } \\
\text { offspring, } \\
\text { they will } \\
\text { have the } \\
\text { one- } \\
\text { eighth } \\
\text { of what } \\
\text { you left }\end{array}$ & 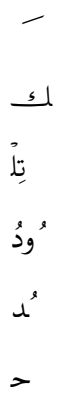 \\
\hline
\end{tabular}




\begin{tabular}{|c|c|c|c|c|c|c|c|c|c|c|c|c|c|}
\hline & \multicolumn{13}{|c|}{ Dr. Khaled Nagib El-Sebaie Khalifa } \\
\hline & & & & & & & & & & & & & 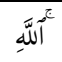 \\
\hline $\begin{array}{l}1 \\
1\end{array}$ & $\begin{array}{l}\text { inheri- } \\
\text { tance }\end{array}$ & $\begin{array}{l}\text { sibling } \\
\text { (a } \\
\text { brother } \\
\text { or } \\
\text { a } \\
\text { sister) }\end{array}$ & $\begin{array}{l}\text { attribu- } \\
\text { tion } \\
\text { and } \\
\text { gender } \\
\text { (brother- } \\
\text { hood; } \\
\text { a male } \\
\text { or } \\
\text { a female) }\end{array}$ & $\begin{array}{l}\text { a brother } \\
\text { or } \\
\text { a sister }\end{array}$ & $\begin{array}{l}\text { /kalālah/* } \\
\text { has } \\
\text { sibling } \\
\text { (a brother, } \\
\text { a } \\
\text { sister } \\
\text { or both) }\end{array}$ & $\begin{array}{l}1 / 6 \\
\text { for } \\
\text { each } \\
\text { brother } \\
\text { and } \\
\text { sister } \\
\text { (only } \\
\text { two) } \\
\text { or } 1 / 6 \\
\text { for one } \\
\text { if only } \\
\text { one }\end{array}$ & & $\begin{array}{l}\text { he is } \\
\text { inheri- } \\
\text { table } \\
\text { يُورَث }\end{array}$ & $\begin{array}{l}4 / 6 \text { for } \\
\text { his/her } \\
\text { wife/ } \\
\text { husband } \\
\text { in case of } \\
\text { two } \\
\text { siblings, } \\
\text { or } \\
5 / 6 \text { for } \\
\text { his/her } \\
\text { wife/ } \\
\text { husband } \\
\text { in case } \\
\text { of one } \\
\text { sibling }\end{array}$ & لَكَ & $\begin{array}{l}\text { /wa?in } \\
\text { kāna } \\
\text { rajulun } \\
\text { yūrabu } \\
\text { kalālatan } \\
\text { ?awimra- } \\
\text { ?atan } \\
\text { Walahu } \\
\text { ?axun ?aw } \\
\text { ?uxtun } \\
\text { Falikuli } \\
\text { wāhidin } \\
\text { minhuma- } \\
\text { ssudusu/ }\end{array}$ & $\begin{array}{l}\text { and if it } \\
\text { is an } \\
\text { inheri-- } \\
\text { table } \\
\text { kalālatun } \\
\text { man/wo } \\
\text { man, (left } \\
\text { neither } \\
\text { ascen- } \\
\text { dants nor } \\
\text { descen- } \\
\text { dants), } \\
\text { but has } \\
\text { left a } \\
\text { brother } \\
\text { or a } \\
\text { sister, } \\
\text { each one } \\
\text { of them } \\
\text { has the } \\
\text { one-sixth }\end{array}$ & 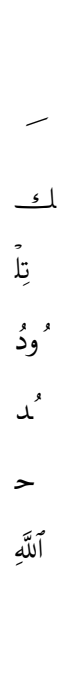 \\
\hline $\begin{array}{l}1 \\
2\end{array}$ & $\begin{array}{l}\text { inheri- } \\
\text { tance }\end{array}$ & $\begin{array}{l}\text { sibling } \\
\text { (brothe } \\
\text { rs } \\
\text { and } \\
\text { sisters) }\end{array}$ & $\begin{array}{l}\text { attribu- } \\
\text { tion } \\
\text { and } \\
\text { gender } \\
\text { (brother- } \\
\text { hood; } \\
\text { more } \\
\text { than one } \\
\text { male and } \\
\text { more } \\
\text { than one } \\
\text { female) } \\
\text { indefinite } \\
\text { number }\end{array}$ & $\begin{array}{l}\text { brothers } \\
\text { and } \\
\text { sisters }\end{array}$ & $\begin{array}{l}\text { /kalālah/* } \\
\text { Has } \\
\text { siblings } \\
\text { (brothers } \\
\text { and } \\
\text { sisters) }\end{array}$ & $\begin{array}{l}\text { all } \\
\text { of } \\
\text { them } \\
\text { are } \\
\text { shared } \\
\text { in } \\
\text { the } \\
1 / 3\end{array}$ & $\begin{array}{l}\text { after } \\
\text { consm- } \\
\text { ing } \\
\text { a } \\
\text { bequest } \\
\text { or a } \\
\text { debt } \\
\text { (with } \\
\text { no } \\
\text { loss) }\end{array}$ & $\begin{array}{l}\text { he is } \\
\text { inheri- } \\
\text { table } \\
\text { يُورَثر }\end{array}$ & $\begin{array}{l}2 / 3 \text { for } \\
\text { his wife }\end{array}$ & 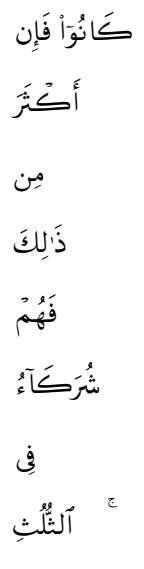 & 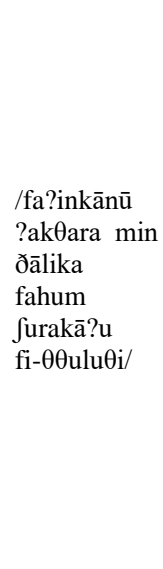 & $\begin{array}{l}\text { if they } \\
\text { are } \\
\text { more } \\
\text { than that, } \\
\text { they } \\
\text { share } \\
\text { the one- } \\
\text { third }\end{array}$ & 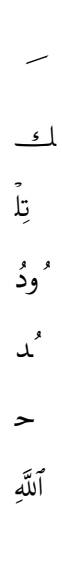 \\
\hline
\end{tabular}


Inheritance Rules in Surat Al-Nisa' (Women) as a Contemporary Reading of Two Translations; Y. Ali (1979) and M. Haleem (2004): An Appraisal Study

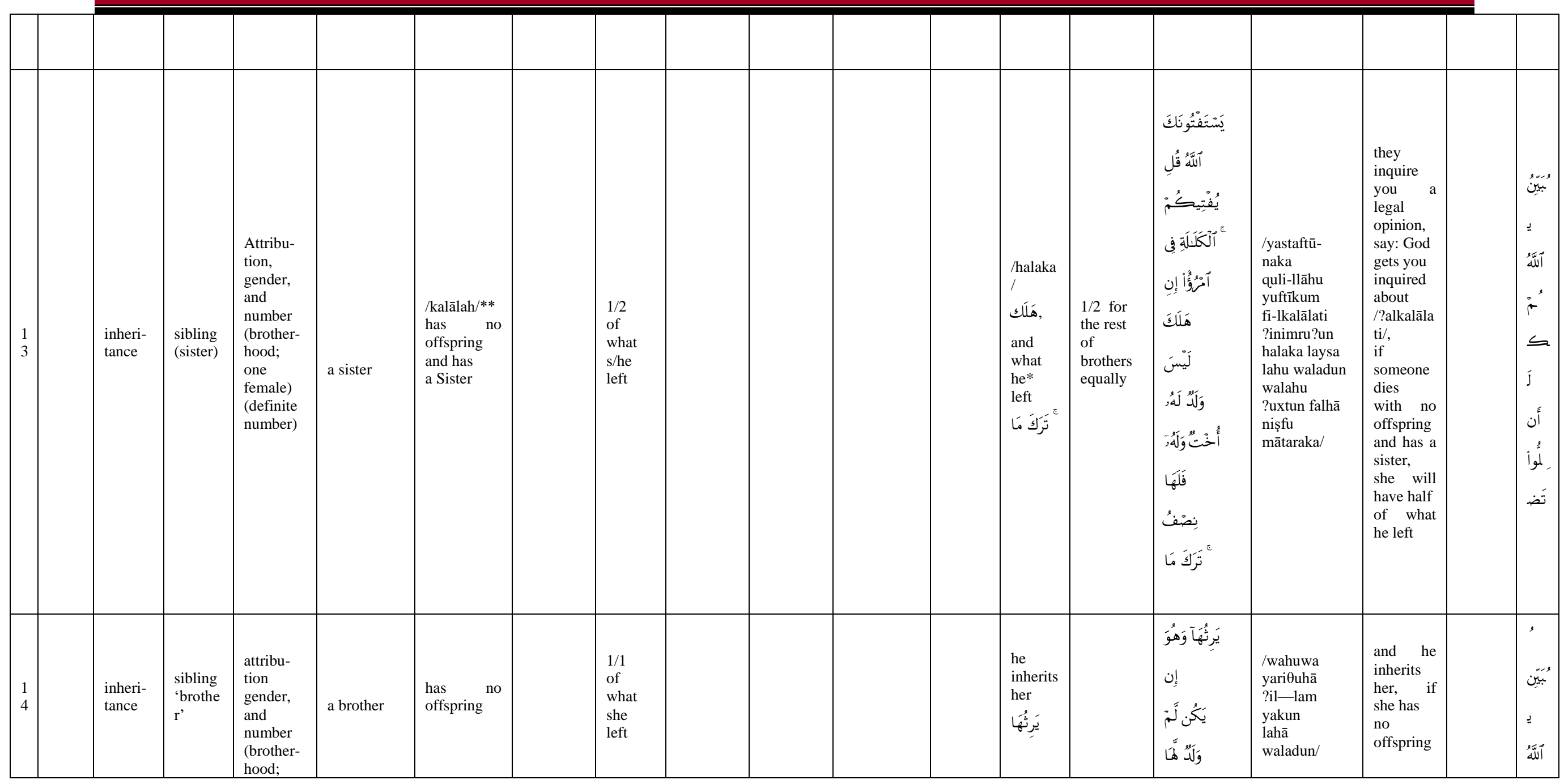




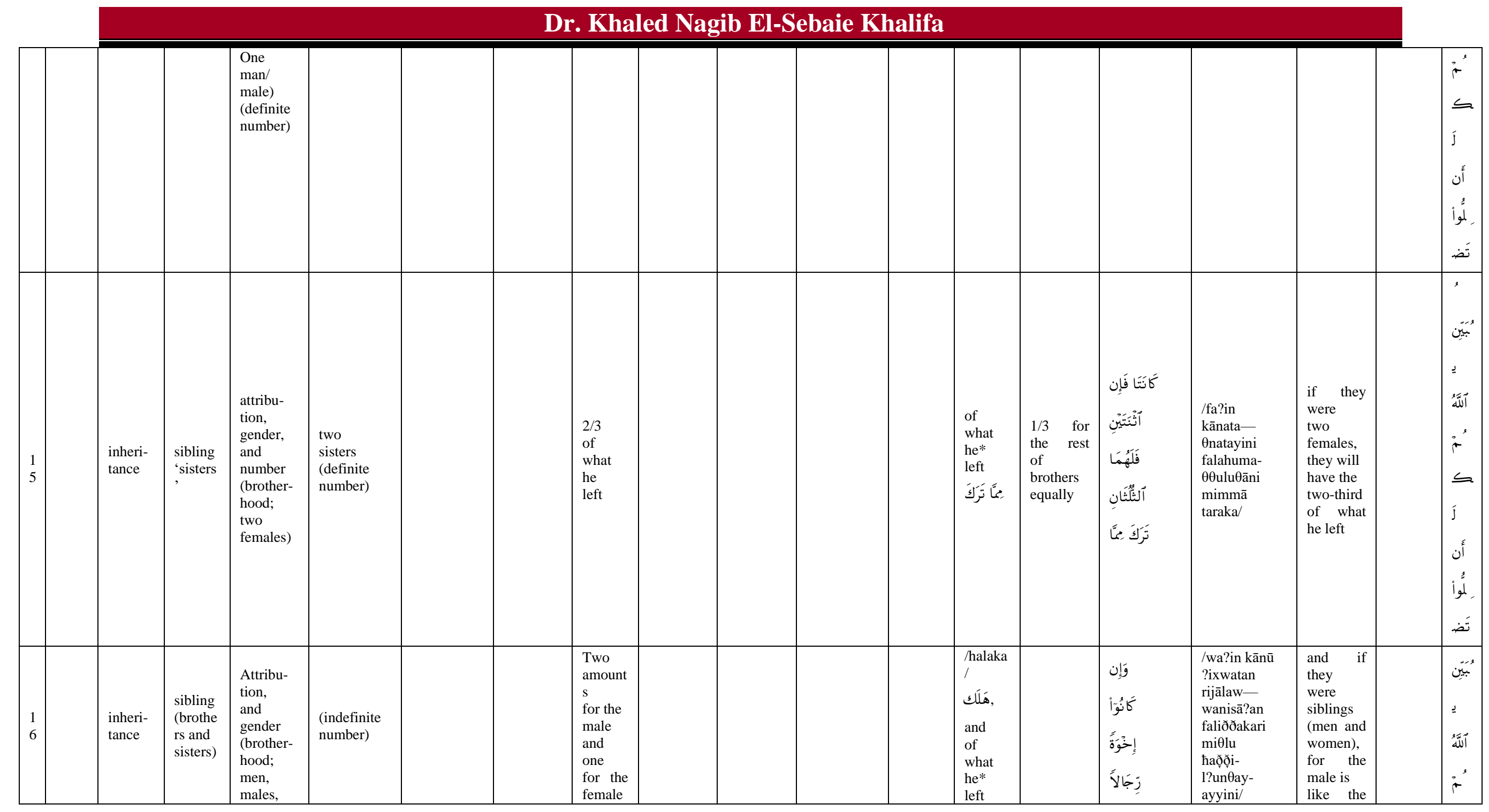


Inheritance Rules in Surat Al-Nisa' (Women) as a Contemporary Reading of Two Translations; Y. Ali (1979) and M. Haleem (2004): An Appraisal Study

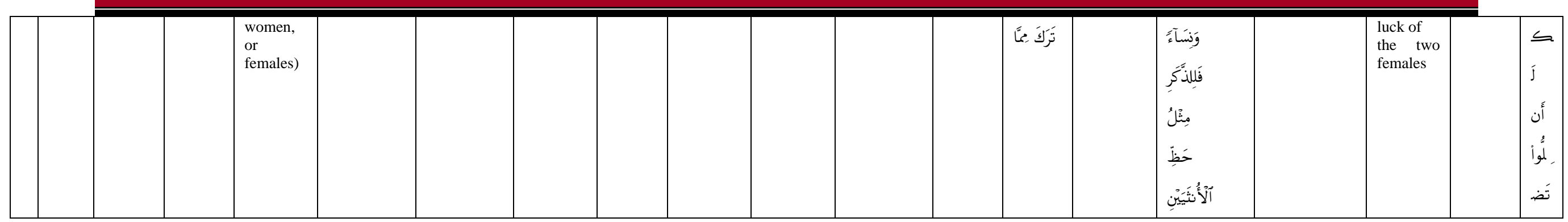

He*: The deceased person

They*: Wives

You*: Husbands

/kalālah/*: A person, whether a man or a woman, has neither ascendants nor descendants, but $\mathrm{s} /$ he is married (has current spouse).

/kalālah/**: A person, whether a man or a woman, has neither ascendants nor descendants nor spouse, as s/he is not married. 


\section{Dr. Khaled Nagib El-Sebaie Khalifa}

\subsection{Conclusion}

This paper includes the application of the theories to the verses of inheritance at study concerning the Qur'anic concepts and terms, clarifying the most important semantic role of them, such as, bequest and inheritance, bequest and recommendation, and portion and fortune. Syntagm and paradigm are also illustrated to clarify how one can infer the meaning, hence, how to render the ST. The paper offers a transcendental point of view of deducing the most appropriate meaning of ST, and attaining a new perspectives of the verses at study. It presents a number of comparisons between bequest and inheritance, portion and fortune in life and death. Besides, according to Newmark, it presents features of cultural and authentic translation. In detail, it surveys how Martin's appraisal model and others are applied to verses at study. It shows the rhetoric difference between the male and the two females through beardsley's concept of Simile. It presents a suggested specimen of distributing inheritance.

Through a number of titles and sub-titles, and using the most authentic Arabic dictionaries and sources, the researcher reaches to some variable results.

1- As for inheritance rules, the researcher proofs that bequest has priority to inheritance, because the former has been mentioned 12 times, and the later has been mentioned 3 times.

2- The structure /yūşīkumu-llāhu fî ?awlādikum li-ððakari miӨlu

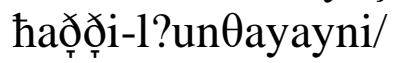

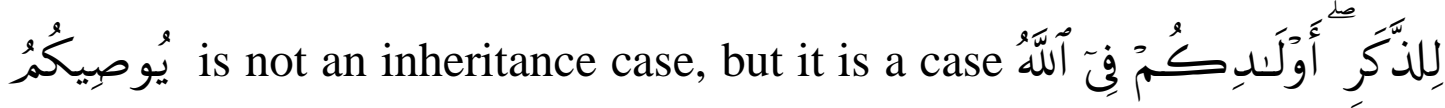

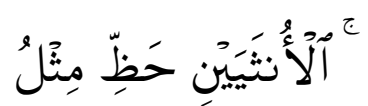

of distributing one's wealth while he is still alive. Yet, it is provided by one condition;

the number of female is as twice as the number of males.

3- Rhetorically, as number 2 is a case of distributing one's wealth while he is still

alive, the two females have to choose their fortune first as they are the basic of

distribution, and what they take is like what they leave for the male.

4- Bequest relates to people who have a biological relationship and to the close 
relatives, who are not apparent heirs, (offspring and begetters).

5- Inheritance relates to people who are responsible for guardianship and

patronage, whether they have a biological relationship or not, (sons and parents).

6- Bequest, as an Arabic constituent, provides two main aspects; bequest and

recommendation, where the former is financial and the later is ethical.

7- /?alhad̛ðָ/ الحظ (i.e. 'fortune') belongs to life, while /?a-nnaşīb/ النصيب (i.e. 'portion') belongs to death. This is consistent throughout the whole Text.

8- Syntagm and paradigm assert that the male is not excluded out of the context of inheritance, when applying the verse

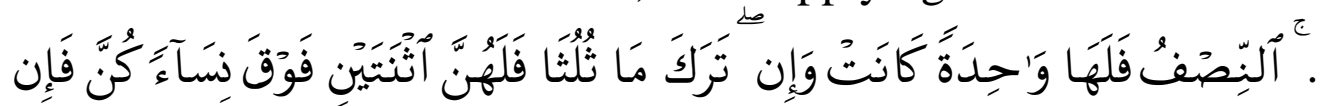

/fa? in kunna nisā?an fawqa- $\theta$ natayni falahunna $\theta$ ulu $\theta \bar{a}$ mā taraka wa?in kānat wāhidatan falaha-nnişfu/, but he is included.

9- Paternal uncle and/or his offspring is perfectly excluded out of the process of inheritance, where inheritance is exclusive to the family blood line.

10- The grandson of the deceased father is an apparent heir, where he is not supposed to be favoured the so-called الوصية الواجبة /?al-waşiyyah ?al-wājibah/.

11- Equation is the main principle of distributing one's wealth when he is deceased, unless what is literally mentioned in the Qur'anic Text.

\section{Recommendations for Future Research}

The paper can be taken as foundational work to develop the further similar authentic-based researches on the same linguistic category. Future research work can reevaluate the findings of the study both synchronically and diachronically across different cultures worldwide. It would be interesting to examine the interactions between the two types of translations; cultural and authentic. Historically, different societies and cultures of the Islamic world have constructed their own distinctive types of how to understand the Qur'anic Text only through the process of Transitive Instruction (التلقي عن طريق النقل فقط). While the peculiar cultures pertaining to different countries may moderate the representation of what is reasonable (i.e. 'authentic/heteroglossic'), and what is unreasonable (i.e. 'cultural/monoglossic'). It is necessary to compare them cross- 


\section{Dr. Khaled Nagib El-Sebaie Khalifa}

culturally in the context of the increasingly global, postmodern Islamic cultural environments. The researcher would like to turn the readers over to the books of the authors; M. D. Shahrur, and M. Arkun. This may facilitate understanding the various types comprehension and interpretation, hence, the translation of the Qur'anic Text. 


\section{Primary Sources}

\section{References}

Abdel Haleem, M. A. S. (2004). The Qur'an: a New Translation. Oxford, Oxford

University press. The Holy Qur'an: Translation and Commentary. Ali, A. Yusuf. (1979). The Holy Qur'an: Translation and Commentary. King Fahd

Complex of Printing the Holy Qur'an, Reyad: Saudi Arabia.

\section{Secondary Sources}

Abbott, B. (2004). Definiteness and Indefiniteness, The Handbook of Pragmatic. L.

Horn and G. Ward (eds.) Malden. MA: Blackwell.

------- (2006). Definite and Indefinite, Encyclopedia of Language and Linguistics.

Abrams, M. H. (1971). A Glossary of Literary Terms. New York: Holt, Rinehart and

Winston, Inc.

Ali, A. Y. (1946). The Holy Qur'an Translation and Commentary. Islamic

Propagation Center International.

Arberry. A. J. (1955). The Holy Qur'an and English translation of the meanings. Beirut:

Dar An-Nafaes. Printing, Publishing, and distribution.

Ariel, M. (1990). Defining Pragmatics. Cambridge. Cambridge University Press.

Asher, R. E. (1994). The Encyclopedia of Language and Linguistics. 10 volumes. 1st

Edition. New York: Pergamon.

Baker, M. (2006). In Other Words: A Course Book on Translation. London and

New York: Routledge Taylor and Francis Group.

Baker, M. (2008). Routledge Encyclopedia of Translation Studies. New York: Routledge,

Taylor and Francis Group.

Bakhtin, M. (1981). The Dialogical Imagination. M. Holquist, (ed.), C. Emerson \& M.

Holquist, (trans.), Austin, University of Texas Press.

Barlas, A. (2002). Unreading Patriarchal Interpretations of the Qur'an. Austin:

University of Texas Press. 


\section{Dr. Khaled Nagib El-Sebaie Khalifa}

Barthes, R. (1967). Elements of Semiology. (Trans. Annette Lavers \& Colin Smith).

London: Jonathan Cap.

Bastin, G. L. (2011). Adaptation. (M. Gregson, Trans). In M. Baker and G. Saldanha

(Eds.), Routledge Encyclopedia of Translation Studies. (pp. 3-6). London and New

York: Routledge Taylor and Francis Group. (Original work published in 1998)

Beardsley, A. V. (1967). The early work of Aubrey Beardsley. Dover Publication. New

York.

Beck, L. and Keddie, N. (1978). Women in the Muslim World. Cambridge, Massachusetts:

Harvard University Press.

Beeston, A. F. L. (1970). The Arabic language today. London: Hutchinson and Co

(Publishers) Ltd.

Bell, R. (1991). Translation and Translating: Theory and Practice. London and New

York: Longman.

Birner, J. B. (1994). Introduction to pragmatics. Malden, MA: Wiley-Blackwell.

Bloomfield, L. (1984). Language. Chicago: The University of Chicago Press.

Bourdieu, P. (1986). Distinction: A Social Critique of the Judgement of Taste. Cambridge,

Polity.

Buhler, K. (1990). Theory of Language: The Representational Function of language.

Translated by Donald Fraser Goodwin, John Benjamin Publishing Company,

Amsterdam/Philadelphia.

Butler, J. (2002). Gender Trouble: Feminism and the Subversion of Identity. Routledge.

New York and London. 
Catford, J. C. (1965). A Linguistic Theory of Translation. London: Oxford University

press.

Catherine Z. E. (1997). The Philosophy of Nelson Goodman: Selected Essays. Series

Editor. Garland Publishing, Inc. New York and London.

Chafe, W. L. (1994). New Directions in Cognitive Linguistics. John Benjamin publishing

Company. Amsterdam / Philadelphia.

Chafe, W.L. \& J. Nichols, (eds), (1986). Evidentiality: The Linguistic Coding of

Epistemology. Norwood, N. J., Ablex.

Chaudhry, Z. (1997). The Myth of Misogyny: A Reanalysis of Women's Inheritance

in Islamic Law. 61 Alb. L. Rev. 511.

Chomsky, N. (1965). Aspects of the Theory of Syntax. The M.I.T. Press, Massachusetts,

Institute of Technology Cambridge, Massachusetts.

Clark, E. (1992). Conventionality and Contrast: Pragmatic Principles with Lexical

Consequences. In Adrienne Lehrer and Eva Fedder Kittay (eds), Frames,

Fields, and Contrasts: New Essays in Semantic and lexical organization. 171

- 188. Laurence Erlbaum.

Clarke, J. F. (1992). Common Sense in Religion: A Series of Essays. Published by

Houghton, Mifflin and company. New York.

Coulson, N. J. (1971). Succession in the Muslim Family. Cambridge University Press,

London, p. 108.

Coulson, N. and Hinchslife, D. (1978). Women and Law Reform in Contemporary

Islam. Lois Beck and Nikki Keddie, Women in the Muslim World, Cambridge,

Massachusetts: Harvard University Press.

Christopher L. (1999). Definiteness. Cambridge University Press. 


\section{Dr. Khaled Nagib El-Sebaie Khalifa}

Christophersen, P. (1939). The Articles: A Study of Their Theory and Use in English.

Copenhagen: E. Munksgaard, London: H. Milford.

Cruse, D. A. (1986). Lexical Semantics. Cambridge, U.K. : Cambridge University Press.

------- (2000). Meaning in language: An Introduction to Semantics and Pragmatics.

Oxford: Oxford University Press.

Press.

(2004). Meaning in Language. Oxford, U.K. : Oxford University

Crystal, D. (1971). Linguistics. London: Penguin Books Ltd.

(1995). The Cambridge Encyclopedia of the English Language.

Cambridge:

Cambridge University Press.

------- (1996). The Cambridge Encyclopedia of the English language.

Cambridge:

Cambridge University Press.

------ (2004). A Dictionary of Linguistics \& Phonetics. Fifth Edition.

Blackwell

Publishing Ltd. D. Newby, (p .15)

Economou, G. (2009). Acts of Love, Ancient Greek Poetry from Aphrodite's Garden.

New York: The Modern Library, Random House.

Edmonds and Hirst. (2002). Near Synonymy and Lexical Choice. Computational

linguistics, 28 (2): $105-144$.

Eggins, S. \& Slade, D. (1997). Analysing Casual Conversation. London, Cassell.

Elewa, A. (2006). To be a Translator. Cairo: /?alfalāћ/ Foundation for Translation, Publication and Distribution.

------ (2011). The Grammar of Translation: A Five-Level Course on the Theory and Practice of Translation. Five volumes. Cairo: New Vision pours Traduction et Culture.

Eliot, T. S. (1920). Hamlet and His Problems. Published in The Sacred Wood.

Emerson, R. W. (2002). Emerson on Transcendentalism: Milestones of Thought. Ed.

Edward L. Ericson. New York: The Continuum Publishing Company.

Evens, et. al. (1986). Analyzing Language in Restricted Domains: SubLanguage 
Description and Processing. Lawrence Erlbaum Associates, Publishers. Hillsdale,

New Jersey. London.

------ (1986). Annual Review of Information Science and Technology. Published and

Distributed by Information Today, Inc.

Fairclough, N. (1992). Discourse and Social Change. Cambridge, UK, Polity Press.

Foucault, M. (1978). The History of Sexuality Volume I: An Introduction. Translated from

the French by Robert Hurley. Pantheon Books, New York.

Givon, T. (1992). The Story of Zero: The Grammar of Referential Coherence as Mental

Processing Instructions. John Benjamin publishing Company. Amsterdam/

Philadelphia.

Gunawan, A. (2004), Women and The Glorious Qur'an: An Analytical Study of women

Related Verses of Surat An-Nisa'. under I.B.3, The Concept of Marriage from the

Islamic Point of View.

Halliday, M. A. K. and Hasan, R. (1976). Cohesion in English. London: k 8 Longman.

Hawkins, J. H. (1978). Definiteness and Indefiniteness: A Study in Reference and

Grammaticality Prediction. John Benjamin publication Company.

Hilali, M. T. D. and Khan, M. M. (1997). Translation of the Meanings of the Nobel

Qur'an in the English Languish. King Fahd Complex for the Printing of the Holy

Qur'an, Madinah, K. S. A.

Hitti, P. K. (1937). History of the Arabs. Sixth Edition. Macmillan and Co., Limited. ST.

Martin's Street, London.

Hornby, A. S. (1999). Oxford Advanced Learner's Dictionary. Oxford: Oxford

University Press.

Hjorland, B. (2011). Evaluation of an Information Source Illustrated by a Case Study: 


\section{Dr. Khaled Nagib El-Sebaie Khalifa}

Effect of Screening for Breast Cancer. Journal of the American Society for

Information Science and Technology.

Hobbs, and Sanders et al. (1992). Building Coherence and Cohesion: Task-Oriented

Dialogue in English and Spanish. John Benjamin publishing Company.

Amsterdam / Philadelphia.

Huddleston, R. (2002). English Grammar: An Outline. Cambridge: Cambridge University Press.

Hurford, J. R. and Heasley, B. (1996). Semantics: A course book. Cambridge:

Cambridge University Press.

Hunston, S. (2000). Evaluation and the Planes of Discourse, in Evaluation in Text:

Authorial Stance and the Construction of Discourse. Huston, S. \& Thompson, G.

(eds), Oxford, Oxford University Press.

Hyland, K. (1996). 'Writing Without Conviction: Hedging in Science Research Articles'.

Applied Linguistics 17 (4): 433-54.

Hymes, Dell. (1992). The Concept of Communicative Competence Revisited. Thirty Years

of Linguistic Evolution.

Johnstone, Barbara. (2008). Discourse Analysis. $2^{\text {nd }}$ Ed. Blackwell Publishing Ltd.,

Singapore.

Khan, M. M. (1997). The Translation of the Meaning of Sahih AlBukhari. Riyadh,

Saudi Arabia: Darussalam Publishers and Distributers.

Khan, H. (2007). The Islamic Law of Inheritance: A Comparative Study of Recent

Reforms in Muslim Countries. Oxford University Press, Karachi.

Khoo. C. S. G. \& Na, J. C. (2007). Semantic Relations in Information Science. Annual

Review of Information Sciences and Technology. Volume 40, Issue 1.

Kirvalidze, N. (2014). Three-Dimensional World of Similes in English Fictional Writing. 
Sino-US English Teaching 11(1), 25-39.

Leech, G. (1981). Semantics: The Study of Meaning. England: Penguin Books Ltd.

------ (1983). Principles of Pragmatics. London and New York: Longman Group

Limited.

Lowell, A. (1916). Men, Women and Ghosts. New York: Macmillan.

Lowth, Robert. (1762). A Short Introduction to English Grammar.

Lyons, J. (1977). Introduction to Theoretical Linguistics. Cambridge:

Cambridge

University Press.

------ (1984). Semantics. Two volumes. Cambridge: Cambridge University Press.

(1999). Language and Linguistics: An Introduction. Cambridge:

Cambridge

University Press.

Manfred, Stede. (2000). The Hyperonym Problem Revisited: Conceptual and Lexical

Hierarchies in Language Generation. Association for Computational Linguistics.

Retrieved in January 2014.

Marso, Lori. Jo. (2006). Feminist Thinkers and the Demands of Femininity. Routledge

Taylor \& Francis Group, New York.

McArthur, Tom. (1992). The Oxford Companion to the English language. Oxford

University Press. New York.

McLuhan, Marshall. (1977). Symbolic Landscape. Four Quartets. ed. Bernard, Bergonzi.

London: The Macmillan Press Ltd.

Martin, J. R. (1995). Reading Positions/Positioning Readers: Judgement in English,

Prospect: a Journal of Australian TESOL. 10 (2): 27-37.

in Evaluation in

Text. Hunston, S. \& Thompson, G. (eds), Oxford, Oxford University Press.

Martin, J. R. and Rose, D. (2003). Working with Discourse: Meaning Beyond The

Clause. London, New York: Continuum. 


\section{Dr. Khaled Nagib El-Sebaie Khalifa}

Martin, J. R. and White, P. R. R. (2005). The Language of Evaluation Appraisal in

English. Balgrave, Macmillan.

Matthews, P. H. (2003). The Concise Dictionary of Linguistics. Oxford:

Oxford

University Press.

Meyer, P. G. (1997). Hedging Strategies in Written Academic Discourse. Berline \& New

York, Walter de Gruyter.

Miller, G. A. (1998). Nouns in Word Net in Christiane Fellbaum (editor), Wordnet:

An Electronic Lexical Database. MIT Press, ISBN 0-262-06197$\mathrm{X}$.

Moi, T. (1999). What is a Woman? and Other Essays. Oxford. Oxford University Press.

Mousa and Dahroug, (1992). In M. Baker and G. Saldanha (Eds.), Routledge

Encyclopedia of Translation Studies. London and New York: Routledge Taylor and Francis Group.

Mustapha, Hassan. (2008). (Eds.). Encyclopedia of Translation Studies. London and New

York: Routledge Taylor and Francis Group.

Munday, J. (2001). Introducing Translation Studies: Theories and applications. London

and New York: Routledge Taylor and Francis Group.

Munday, Jeremy. (2008). Introducing Translation Studies: Theories and Applications.

Second Edition, Routledge Taylor \& Francis Group.

Nasution, Khoiruddin. (2009). The Phenomenon of Polygyny in Contemporary Malaysia,

Al-Jami'ah (Journal of Islamic Studies), Vol. 39 Number 1 January-June 2001, p. 38,

and others.

Newby, D. (2012). Grammar. In M. Byram (ed.) Routledge Encyclopedia of Language

Teaching and Learning (revised 2nd edition). London: Routledge. Newmark, P. (1984). Approaches to Translation. Oxford: Pergamon Press Ltd.

(1988). A Textbook of Translation. UK: Prentice Hall International 
Matters Ltd.

(1993). Paragraphs on Translation. Clevedon. UK: Multilingual (2001). About Translation. Clevedon. UK: Multilingual Matters Ltd.

Nilsen, D. L. F. and Nilsen, A. P. (1975). Semantic Theory: A Linguistic Perspective.

Massachusetts, Rowly: Newbury House Publishers, Inc.

Noel, C. and Doreen, H. (1978). Women and Law Reform in Contemporary Islam, in Lois

Beck and Nikki Keddie, 'Women in the Muslim World'. Cambridge,

Massachusetts: Harvard University Press.

Nord, C. (1997). Translating as Purposeful Activity: A Prospective Approach. University

of Applied Sciences of Magdeburg-Stendal, Germany.

Palmer, F. (1973). Grammar. England, Middlesex, Harmondsworth: Penguin Books Ltd.

------- (1988). Semantics. Cambridge: Cambridge University Press.

Palumbo, Giuseppe. (2009). Key Terms in Translation Studies. Continuum SE17NX.

International Group, The Tower Building 11York Road London

Pickthall, M. M. (1997). The meaning of the Glorious Koran. USA: Meridian, Penguin

Books.

Pearce, M. (2007). The Routledge Dictionary of English Language Studies. London and

New York: Routledge Taylor and Francis Group.

Powers, David S. (1993). The Islamic Inheritance System: A SocioHistorical Approach.

in Chibli Mallat, and Jane Connors (eds) Islamic Family Law. London: Graham \&

Trotman, PP. 27-29.

Quirk, R. and Greenbaum, S. (1977). A University Grammar of the English. London:

Longman Group Limited.

Quirk, R., Greenbaum, S., Leech, G. and Svartvik, J. (1997). A Comprehensive

Grammar of the English Language. England, Essex, Harlow, Edinburgh Gate: 


\section{Dr. Khaled Nagib El-Sebaie Khalifa}

Addison Wesley Longman Limited.

Reiss, k. and Vermeer, H. J. (2014). Towards a General Theory of translational action:

Scopos Theory Explained. Translated from the German by Christiane Nord.

Rutledge. New York.

Richards, I. A. (1936). The Philosophy of Rhetoric. London, Oxford \& New York: The

Oxford University Press.

Riley, D. (2003). Am I That Name? Feminism and the Category of 'Women' in History.

Palgrave, Macmillan.

Salloum, H. and James, P. (1996). Arabic Contribution to the English Vocabulary:

English Word of Arabic Origin: Etymology and History. Beirut. Lebanon:

Librairie du Liban publishers.

Shahrour, M. D. (1992). The Book and The Qur'an. Al-Ahali Publishers, Damasks.

------ (2000). Towards New Basics of the Islamic Jurisprudence:

Women Jurisprudence.

Al-Ahali Publishers, Damasks.

Stageberg N. C. (1965). An Introductory English Grammar. University of Northern Iowa.

Library of Congress, Catalogue Card Number:77-129006.

Tahir, M. (1987). Personal Law in Islamic Countries, (1995). Law in Islamic Countries:

History, Texts and Analysis, Revised Edition. p.p. 173-174, E. H.

------ (2017). Introduction to Muslim Law. Universal Law

Publishing.

Voloshinov, V. N. (1995). Marxism and the Philosophy of Language: Bakhtinian

Thought -- An Introductory Reader. Translated by S. Dentith,

L. Matejka, \& I.R.

Titunik, London, Routledge.

Wahba, M. (1988). Critic of the Pure Reason. Translation of A. Kant's Germany book

Critic der reinen Bernunft. Markaz Al-Inma' Al-Qawmy. Beirut, Lebanon.

Wayne, T. K., (2006). Encyclopedia of Transcendentalism. New York: Facts On File. 
Wardhaugh, R. (1998). An Introduction to Sociolinguistics. USA, Massachusetts:

Blackwell Publishers Inc.

White, P. R. R. (2000). Beyond Exchange: Appraisal Systems in English, in Evaluation

in Text. Hunston, S. \& Thompson, G. (eds), Oxford, Oxford University Press.

White, P. R. R. (2002). Attitude and Arguability: Appraisal and the Linguistics of

Solidarity. Text - Special Edition on Appraisal.

Widdowson. H. G. (2005). Text, Context, Pretext. Critical Issues in Discourse Analysis:

Critical Issues in Discourse Analysis. Blackwell Publishing.

Wouden, Ton van der. (1997). Negative Contexts: Collocation, Polarity and Multiple Negation. Routledge.p. 243.

Yule, G. (1997). The Study of Language. Cambridge: Cambridge University Press.

Zidan, A. and Zidan, D (1991, p. 5). The Glorious Qur'an. Text and Translation. Islamic

Inc. Publishing and Distribution.

\section{Arabic Sources}

Al-Sahafi'i, H. M. F. (2008). Al-Dalil Al-Mufahras Li-Alfad Al-Qur'an Al-Karim. Dar

Al-Salam, Publishers and Distributers.

Anonymous. (second half of the fourth century A. H.), Rasa'il Ikhwan As-Safa, (The

Brethren of Purity and Loyal Friends).

An-nasafy, A. A. M. (2008). Tafsiru-nnasafy madariku-ttanzīli wa $\hbar a q \bar{a} ?$ iqu-tta?wīl/

(?a-nnasafi's exegesis: (ways of) understanding the revelation and the realities of

interpretation). Beirut: Dāru-LMaלārif.

Ibn Kathir, E. I. (2004). Tafsir Ibn Kthir (The exegesis of the Qur?ān). Three volumes.

Cairo: Maktabatu-S'Safâ.

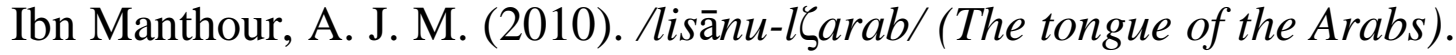
Twenty volumes. Kuwait: Dāru-Nnawādir.

Al-Eshbily, Ibn Osfour. (1996). Al-Mumti' Al-Kabir fi At-Tasrif. Librairie de Liban

Publishers. 


\section{Dr. Khaled Nagib El-Sebaie Khalifa}

Al- Nawawi (2005). Al-majmū $\zeta$. Cairo, Maktabat At-Tadamun, Publishers and

Distributers.

Al-Qurtuby (2006). Al-Jami' Li Ahkam Al-Qur'an (The comprehensive (exegesis) of the

Qur'an legislation.) Twenty four volumes. Beirut: Al-Resalah Publishers.

Ar-Razy, M. F. D. (1981). At-Tafsir Al-Kabir (Mafatih Al-Ghaib) (The great exegesis) or

(The keys of the unseen). Thirty two volumes. Lebanon, Beirut: Dar Al-Fikr for

Publishing and Distribution.

As-Suyuty, G. A. (2010). Tafsiru-ljalalayn. (1445-1505 A. D.) (849-911

H.). Dar Al-

Hadith, Cairo.

As-Suyuty, G. A. (2010). Al-Itqan Fi Ulum Al-Qur'an. (Vol. I, p. 231). The General

Egyptian Authority for Book.

As-Sabouny, M. A. (1997). Safwat At-Tafasir (The Prime of Exegeses).Dar As-Sabouny

for printing, publishing, and Distribution.

Dawud, M. M. (2008). Lexicon of Synonyms in the Ever-Glorious Qur?ân./тuডjamu-

lfurūqi-ddilāliyyati fi-lqur?ā ni-lkarīm/. Cairo: Dâru Gharîb.

Mehanna, A. I. (1978). Derasah Hawla Targamat Al-Qur'an Al- Karim. (A Study around

the Translation of the Nobel Qur'an). Dar Al-Sha'b, for Press, Printing and

Distribution.

Qamhawy, M. A. (2009). Al-Burhan fi Tagwid Al-Qur'an (The evidence in the rules of

recitation of the Qur'an). Cairo: Dar Al-Adab.

Sahih Al-Bukhary. (2010).

Sahih Muslim. (2010).

Text of the Current Egyptian Penal Law. (1937). Number 58, that Issued on July $21^{\text {st }}$

(1937), and its Modulations until April $2^{\text {nd }} 2018$, Items Number 272-277.

\section{Dissertations}

Al-Ezabi, A. A. (1990). Semantic and Pragmatic Equivalence in Translation, M. A. 
Thesis. Faculty of Languages and Translation in Cairo: Al—Azhar University.

Al-Gazzar, I. M. (2011). A Linguistic Study of Grammatical Shift in Some Qur'anic

Verses and its Rendering into English, Ph. D. Thesis. Faculty of Languages and

Translation in Cairo: Al-Azhar University.

Mpouli, S. (2016). Automatic annotation of similes in literary texts. $\mathrm{Ph}$. D. thesis,

Universite Pierre et Marie Curie-Paris VI.

Muhammed, A. G. A. (2017). Translating Metonymy in the Holy Qur 'an: Surat An-

Nisa' as a Case Study, English/Arabic/English Translation and Interpreting. M. A.

Sciences.

thesis, The American University of Sharjah, College of Arts and

Sahlgren, M. (2006). The Word-Space Model Using Distributional Analysis to Represent

Syntagmatic and Paradigmatic Relations between Words in High-Dimensional

Vector. A Ph. D. Dissertation, Stockholm University.

\section{Interviews}

Prophessor Fawzia El-Sadr asserts 'Translation is interpretation from SL into TL (2019).

considering the nature of the TL and its culture.', on July $10^{\text {th }}$, The researcher heads a session in the Writer Union, lecturing about two dichotomies

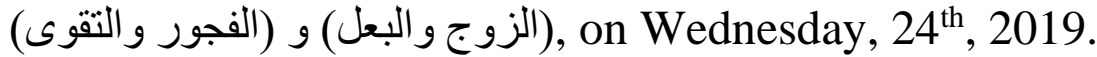

\section{Presidential speeches}

El-Sibsi, B. Q. (2017), on August $14^{\text {th }}$, in a speech for the National Women's Day,

calling for gender equality on inheritance and marriage, he echoes the decree of the

Islamic Fatwas by the Diwan of Al-Ifta.

\section{Dictionaries.}

Al-Mawrid Al-Hadith. (2009). A Modern English-Arabic Dictionary.

Cambridge International Dictionary of English. (1996). Cambridge:

Cambridge University

Press. 


\section{Dr. Khaled Nagib El-Sebaie Khalifa}

Glossary of Poetic Terms: Objective Correlative. By Eliot, T. S. (18881965).

Longman Dictionary of Contemporary English. (2007, p. 1767).

Longman Dictionary of English language and culture. (1998).

Meriam Webster. (1900, p. 258).

Oxford Advanced Learner's Dictionary. (1999, p. 1270).

Roget's International Thesaurus (1979). London: Harper and Row, Publishers, Inc.

The Congregation of the Arabic Language. (1990).

The Holy Qur'an Segments Thesaurus. (1990). vol. 2, p. 501).

The Oxford Companion to the English Language (1992, pp. 1051-1052).

Webster's new dictionary of synonyms (1993). Lebanon, Beirut: Librairie du Liban.

Wesley, A. (1998) Longman. Longman language activator. England: Longman Group

Ltd.

\section{Arabic Dictionaries}

Ad-Dalil Al-Mufaras Lialfath Al-Qur'an Al-Karim. (2008).

The Concise Lexicon of Classical Arabic /?al-muלjamu-lwajīz/(2006). A.

R. E.: Ministry

of Education Edition

\section{Journals}

Abbott, B. (2002). Definiteness and Proper Names: Some Bad News for the Description

Theory. Journal of Semantics.

Billoo, Y. (2005). Change and Authority in Islamic Law: The Islamic Law of Inheritance

in Modern Muslim States. An Article on Hineonline.

Chomsky, N. (1965). Aspects of the Theory of Syntax. Massachusetts Institute of

Technology Cambridge, Massachusetts. The M. L. T. Press.

Martin, J. R. (1995a). Interpersonal Meaning, Persuasion, and Public Discourse:

67.

Packing Semiotic Punch. Australian Journal of Linguistics 15: 3-

Martin, J. R. (1995). Reading Positions/Positioning Readers: Judgement in English

Prospect: A Journal of Australian TESOL 10 (2): 27-37.

Mpouli, S. (2016). Annotating Similes in Literary Texts. University de Lyon, Lyon 2,

ERIC EA 3083. 
Quine, W. V. O. (2003). Quine and the problem of Synonymy. Peter Pagin, Stockholm

University. (July 2003, pp. 171-197).

The United Nations Human Settlements Program (UN-HABITAT) (2005). under the title

Islam, Land \& Property Research Series, and the sub-title Contextualizing Islamic

Laws of Inheritance, paper \# 6, Islamic Inheritance Laws and Systems,

White, E. H. (1978). Legal Reform as an Indicator of Women's Status in Muslim Nations.

\section{On-Line Sources}

wikipedia.org/wiki/Abdullah_Yusuf_Ali.

Access (Saturday, April 26 $6^{\text {th }}$ 2017).

http://en.wikipedia.org/wiki/Muhammad_Abdel-Haleem.

Access (Tuesday, August $1^{\text {st }}$ 2017).

http://www.thepdfportal.com/languageofevaluationbook_113387.pdf (C) J. R.

Martin and

P. R. R. White (2005).

Access (Wednesday, January $17^{\text {th }}$ 2018).

http://law.bepress.com/expresso/eps/.

Access (Saturday, April 17 $7^{\text {th }}$ 2018).

https://www.google.com.eg/search?client=opera\&q=6.2.2+Women

inheritance.

Access (Friday, October 26 $6^{\text {th }}$ 2018).

https://heinonline.org/HOL/LandingPage?handle=hein.

Access (Monday, November $8^{\text {th }} 2018$ ).

http://www.bzu.edu.

Access (Tuesday, December 11 $1^{\text {th }}$ 2018).

http://www.unc.edu/ ujanel/Simile.htm

Access (Monday, June 10 $10^{\text {th }} 2019$ ).

http://www.thefreedictionary.com/simile

Access (Thursday, July $25^{\text {th }}$ 2019).

http://www.grammatics.com/appraisal

Access (Wednesday, July $31^{\text {st }} 2019$ ).

https://www.popline.org/node/448600

Access (Thursday, August $1^{\text {st }}$ 2019).

https://www.britannica.com/art/objective-correlative

Access (Thursday, August $22^{\text {nd }} 2019$ ).

https://www.researchgate.net/publication/249933005.

Access (Thursday, August $29^{\text {th }}$ 2019).

https://www.popline.org/node/448600

Access (Thursday, August $1^{\text {st }} 2019$ ). 